\title{
The extra-tropical Northern Hemisphere temperature in the last two millennia: reconstructions of low-frequency variability
}

\author{
B. Christiansen ${ }^{1}$ and F. C. Ljungqvist ${ }^{2}$ \\ ${ }^{1}$ Danish Meteorological Institute, Copenhagen, Denmark \\ ${ }^{2}$ Department of History, Stockholm University, Stockholm, Sweden
}

Correspondence to: B. Christiansen (boc@dmi.dk)

Received: 1 November 2011 - Published in Clim. Past Discuss.: 18 November 2011

Revised: 29 February 2012 - Accepted: 1 March 2012 - Published: 18 April 2012

\begin{abstract}
We present two new multi-proxy reconstructions of the extra-tropical Northern Hemisphere $\left(30-90^{\circ} \mathrm{N}\right)$ mean temperature: a two-millennia long reconstruction reaching back to $1 \mathrm{AD}$ and a 500-yr long reconstruction reaching back to $1500 \mathrm{AD}$. The reconstructions are based on compilations of 32 and 91 proxies, respectively, of which only little more than half pass a screening procedure and are included in the actual reconstructions. The proxies are of different types and of different resolutions (annual, annual-to-decadal, and decadal) but all have previously been shown to relate to local or regional temperature. We use a reconstruction method, LOCal (LOC), that recently has been shown to confidently reproduce low-frequency variability. Confidence intervals are obtained by an ensemble pseudo-proxy method that both estimates the variance and the bias of the reconstructions. The two-millennia long reconstruction shows a well defined Medieval Warm Period, with a peak warming ca. $950-1050 \mathrm{AD}$ reaching $0.6^{\circ} \mathrm{C}$ relative to the reference period 1880-1960 AD. The 500-yr long reconstruction confirms previous results obtained with the LOC method applied to a smaller proxy compilation; in particular it shows the Little Ice Age cumulating in 1580-1720 AD with a temperature minimum of $-1.0^{\circ} \mathrm{C}$ below the reference period. The reconstructed local temperatures, the magnitude of which are subject to wide confidence intervals, show a rather geographically homogeneous Little Ice Age, while more geographical inhomogeneities are found for the Medieval Warm Period. Reconstructions based on different subsets of proxies show only small differences, suggesting that LOC reconstructs 50-yr smoothed extra-tropical NH mean temperatures well and that low-frequency noise in the proxies is a relatively small problem.
\end{abstract}

\section{Introduction}

The late Holocene (the last few thousand years) is in many ways comparable to the present period and its climate constitutes the background to which the current climate and the projected future climate should be compared. The amplitude of the natural variability and the response of the climate system to external forcings in late Holocene can help us to understand the consequences and the impacts of coming changes in the forcings, whether they are of natural (e.g. solar and volcanic) or anthropogenic origin. Unfortunately, instrumental records rarely reach further back than to the middle of the 19th century, and for earlier periods it is necessary to deduce climate information from climate proxies, i.e. historical archives or natural recorders of climate such as ice-cores, speleothems, tree-rings, lake and marine sediments, etc. For reviews with discussions of the different kinds of temperature proxy records see, e.g. Bradley (1999); Jones et al. (2009); National Research Council (2006).

A number of temperature reconstructions based on compilations of proxies of different types have been presented in the literature, beginning with Groveman and Landsberg (1979) and with increasing frequency after the much publicized reconstructions by Mann et al. (1998) and Mann et al. (1999). Many of the reconstructions show relatively weak variability, with only little evidence for previous temperature anomalies comparable to those of the 20th century. Most local, regional, hemispheric, and global temperature reconstructions reveal that a generally warmer climate regime persisted sometime between ca. 800-1300 AD and a generally colder climate regime persisted sometime between ca. 1300-1900 AD. The earlier warm period is usually 
referred to as the Medieval Warm Period (MWP) or Medieval Climate Anomaly (MCA), whereas the later colder period is referred to as the Little Ice Age (LIA). It is still not fully established if the temperature anomalies in these periods are fully temporally synchroneous througout the globe, and therefore there exist no universally accepted chronological definitions for the start and end of either period. In particular, the spatio-temporal homogeneity of the MWP on a global or hemispheric scale is still debated (Bradley et al., 2003; Broecker, 2001; Esper and Frank, 2009; Diaz et al., 2011), whereas a homogeneously cold LIA recently seems to be a less contested issue (Juckes et al., 2007; Matthews and Briffa, 2005; National Research Council, 2006; Wanner et al., 2008; Ljungqvist et al., 2012).

In many studies much focus has been placed on comparing the amplitude of the warming during the MWP with that of the recent decades in order to assess whether the recent warming is unprecedented either in magnitude or rate during the past one or two millennia. Less focus has been placed on the LIA, despite the fact that the amplitude of its coldest period (presumably the 17th century) is perhaps the biggest uncertainty in the climate of the millennium (Frank et al., 2010) and that a better understanding of the amplitude of this cooling is very important for improving our understanding of the climate sensitivity.

Recently, there has been increasing evidence that many reconstructions are based on statistical methods that seriously underestimate low-frequency variability and trends (von Storch et al., 2004; Bürger and Cubasch, 2006; Zorita et al., 2007; Smerdon and Kaplan, 2007; Christiansen et al., 2009; Smerdon et al., 2011). In particular, Christiansen et al. (2009) systematically investigated this underestimation in 7 different reconstruction methods using an ensemble pseudo-proxy method. Christiansen (2011) attributed this underestimation partly to sub-optimal use of linear regression models and suggested a method, LOCal (LOC), designed to overcome this problem. The LOC method is based on forward modelling of proxies based on the local temperatures. The local reconstructed temperatures are then averaged to obtain a large-scale (e.g. the Northern Hemispheric) mean temperature. That the LOC method reconstructs low-frequency variability well was confirmed in pseudo-proxy experiments (Christiansen, 2011).

We have previously in Christiansen and Ljungqvist (2011) presented a LOC based multi-proxy reconstruction of the extra-tropical Northern Hemisphere $(\mathrm{NH})$ mean temperature in the last millennium. The 50-yr smoothed (with a running mean filter) reconstruction showed larger lowfrequency variability than previous reconstructions (see Fig. 10 of Christiansen and Ljungqvist (2011)), with a minimum anomaly in the LIA about $1.1^{\circ} \mathrm{C}$ lower than the temperature in the calibration period, 1880-1960 AD. Although its variability was stronger, the LOC reconstruction shared the gradual cooling of the first $800 \mathrm{yr}$ of the millennium with most previous reconstructions.
In this paper we extend the LOC reconstruction back to $1 \mathrm{AD}$, to which end we have compiled a set of 32 proxies. The 32 proxies are a subset of a larger compilation of 91 proxies, all reaching at least back to $1500 \mathrm{AD}$ and which all previously have been shown to respond to temperature (see references in Table 1). We use this large proxy set to present an improved LOC reconstruction of the period since $1500 \mathrm{AD}$. Christiansen and Ljungqvist (2011) used 40 proxies and we expect that the larger number of proxies in the present paper will narrow the confidence interval (Christiansen and Ljungqvist, 2012). Note that the number of proxies above refer to all the considered proxies; only little more than half of them pass the screening and are included in the actual reconstruction. In addition to extending the LOC reconstruction back to $1 \mathrm{AD}$ and improving the reconstruction back to $1500 \mathrm{AD}$, with more proxies, we also present an analysis of the geographical dispersion of temperatures in the LIA and the MWP as well as additional sensitivity tests.

The proxies are described in Sect. 2 and a brief summary of the LOC method together with details about the data processing are given in Sect. 3. The reconstructions are presented in the three subsections of Sect. 4: the two-millennia long reconstruction is discussed in Sect. 4.1, the 500-yr long reconstruction in Sect. 4.2, and the geographical dispersion of the local reconstructions in the LIA and the MWP is discussed in Sect. 4.3. Some discussion of the robustness, the spatial averaging, and the validation is given in Sect. 5. We close with our conclusions in Sect. 6 .

\section{Proxies}

We have compiled a set of 91 temperature proxy records from the extra-tropical $\mathrm{NH}$, all of which reach back to at least $1500 \mathrm{AD}$ and of which 32 reach back to $1 \mathrm{AD}$ (or for the case of Mongolia and Dulan to the first centuries of the first millennium). The proxies are selected according to two criteria: they should have a documented relation to temperature and should have been published in the peer reviewed literature. Table 1 lists the proxies and gives, among other information, their geographical positions, their temporal resolutions, and their original references. Of these 91 proxies, 65, 10, and 16 are of annual, annual-to-decadal, and decadal resolution, respectively. Blue Lake (number 7 in Table 1) and Lake C2 (49) are log-transformed. Since a non-linear relationship is expected between temperature and varve thickness, the log-transformation of varve thickness tends to improve the correlation to temperature and reduce the impact of non-temperature related changes on varve thickness (Loso, 2009).

The geographical distribution of the proxies is shown in the top panel of Fig. 1. Note that a few pairs of proxies share the same geographical position but are based on different archives. The 91 proxies considered in the 500-yr long reconstruction have a reasonable geographical coverage, although 
Table 1. List of the 91 proxies considered. The proxies that extend far enough back to be considered for the two-millennia long reconstructions are shaded. The column "Season" refers to the season in which the proxy has been shown to be most sensitive to temperature. The columns denoted Corr 1 and Corr 2 show the correlation coefficients between the proxy and the local temperature in the periods $1880-$ $1960 \mathrm{AD}$ (Corr 1) and $1880 \mathrm{AD}-$ last year (Corr2). The correlation coefficients are boldfaced when significant at the $1 \%$ level according to a $t$-test that considers all years as independent. The proxies that pass these tests are those included in the reconstructions based on the corresponding calibration periods.

\begin{tabular}{|c|c|c|c|c|c|c|c|c|c|c|c|}
\hline$\#$ & Site & Longitude & Latitude & Proxy type & Sample resolution & Season & First year & Last year & Corr 1 & Corr 2 & Reference \\
\hline 1 & Agassiz Ice Cap & -73.10 & 80.70 & Ice-core $\delta^{18} \mathrm{O}$ & Annual & Annual & 1 & 1972 & 0.17 & 0.19 & Vinther et al. (2008) \\
\hline 2 & Alps & 7.50 & 45.00 & Tree-ring density & Annual & Jun to Sep & 1500 & 2004 & 0.67 & 0.54 & Büntgen et al. (2006) \\
\hline 3 & Austfonna & 24.01 & 79.83 & Ice-core $\delta^{18} \mathrm{O}$ & Annual & Annual & 1500 & 1998 & 0.21 & 0.21 & Isaksson et al. (2005) \\
\hline 4 & Avam-Taimyr & 97.00 & 71.00 & Tree-ring width & Annual & Jun to Aug & 1 & 2003 & 0.39 & 0.28 & Briffa et al. (2008) \\
\hline 5 & Belukha & 86.58 & 49.81 & Ice-core $\delta^{18} \mathrm{O}$ & Annual & Mar to Nov & 1500 & 2000 & 0.00 & 0.09 & Eichler et al. (2009) \\
\hline 6 & Big Round Lake & -68.50 & 69.83 & Varved lake sediments & Annual & Jul to Sep & 1500 & 2003 & 0.38 & 0.34 & Thomas and Briner (2009) \\
\hline 7 & Blue Lake & -150.46 & 68.08 & Varved lake sediments & Annual & Jun to Aug & 1500 & 1999 & -0.28 & -0.06 & Bird et al. (2009) \\
\hline 8 & Bomi-Linzhi & 98.00 & 30.00 & Tree-ring width & Annual & Aug & 1500 & 2002 & 0.38 & 0.48 & Zhu et al. (2011) \\
\hline 9 & Burgundy & 6.00 & 47.00 & Documentary & Annual & Apr to Aug & 1500 & 2003 & 0.32 & 0.50 & Chuine et al. (2004) \\
\hline 10 & Camp Century & -61.13 & 77.17 & Ice-core $\delta^{18} \mathrm{O}$ & Annual & Annual & 1500 & 1967 & 0.03 & 0.03 & Dansgaard et al. (1969) \\
\hline 11 & Central Europe & 8.00 & 46.00 & Tree-ring width & Annual & Jun to Sep & 1 & 2003 & 0.15 & 0.46 & Büntgen et al. (2011) \\
\hline 12 & Central NWT (regional) & -110.00 & 63.00 & Tree-ring density & Annual & Summer & 1500 & 2003 & 0.07 & 0.05 & D'Arrigo et al. (2006) \\
\hline 13 & Chesapeake Bay & -76.40 & 39.00 & Sea sediments & Annual-to-decadal & Warm season & 1 & 1996 & 0.05 & 0.13 & Cronin et al. (2010) \\
\hline 14 & China Stack (regional) & 105.00 & 35.00 & Multi-proxy & Decadal & Annual & 1 & 1990 & 0.72 & 0.31 & Yang et al. (2002) \\
\hline 15 & Colombia Icefield & -117.15 & 52.15 & Tree-ring density & Annual & May to Aug & 1500 & 1998 & 0.22 & 0.27 & Luckman and Wilson (2005) \\
\hline 16 & Colombia Icefield & -117.15 & 52.15 & Tree-ring $\delta^{13} \mathrm{C}$ & Decadal & Winter & 1500 & 1985 & -0.07 & -0.07 & Edwards et al. (2008) \\
\hline 17 & Crete & -37.32 & 71.12 & Ice-core $\delta^{18} \mathrm{O}$ & Annual & Nov to Apr & 1500 & 1973 & 0.41 & 0.39 & Vinther et al. (2010) \\
\hline 18 & Czech Lands & 15.00 & 49.00 & Documentary & Annual & Mar to Jun & 1501 & 2008 & 0.47 & 0.66 & Mǒzný et al. (2012) \\
\hline 19 & Devon Ice Cap & -82.50 & 75.33 & Ice-core $\delta^{18} \mathrm{O}$ & Annual-to-decadal & Annual & 1 & 1973 & 0.66 & 0.62 & Fisher et al. (1983) \\
\hline 20 & Donard Lake & -61.35 & 66.66 & Varved lake sediments & Annual & Jun to Aug & 1500 & 1992 & -0.32 & -0.17 & Moore et al. (2001) \\
\hline 21 & Dulan & 98.00 & 36.00 & Tree-ring width & Decadal & Annual & 155 & 1995 & 0.41 & 0.44 & Zhang et al. (2003) \\
\hline 22 & Dye-3 & -43.49 & 65.11 & Ice-core $\delta^{18} \mathrm{O}$ & Annual & Nov to Apr & 1 & 1978 & 0.33 & 0.35 & Vinther et al. (2010) \\
\hline 23 & ESIB (regional) & 150.00 & 68.00 & Tree-ring width & Annual & Summer & 1500 & 1994 & 0.30 & 0.15 & Briffa et al. (2001) \\
\hline 24 & East China (regional) & 112.00 & 32.00 & Documentary & Decadal & Annual & 1500 & 1995 & 0.83 & 0.81 & Wang et al. (2001) \\
\hline 25 & East China (regional) & 112.50 & 32.50 & Documentary & Decadal & Oct to Apr & 1505 & 1995 & 0.92 & 0.90 & Ge et al. (2003) \\
\hline 26 & Eastern Carpathians & 25.10 & 47.20 & Tree-ring width & Annual & Jul to Aug & 1500 & 2005 & -0.09 & 0.16 & Popa and Kern (2009) \\
\hline 27 & Finnish Lapland & 25.00 & 69.00 & Tree-ring width & Annual & Jun to Aug & 1 & 2005 & 0.41 & 0.41 & Helama et al. (2010) \\
\hline 28 & Forfjorddalen & 15.72 & 68.78 & Tree-ring width & Annual & Jul to Aug & 1500 & 1989 & 0.37 & 0.31 & Kirchhefer (2001) \\
\hline 29 & French Alps & 7.00 & 45.50 & Tree-ring width & Annual & Jun to Aug & 1500 & 2008 & 0.38 & 0.47 & Corona et al. (2011) \\
\hline 30 & GISP2 & -38.50 & 72.60 & Ice-core $\delta^{18} \mathrm{O}$ & Decadal & Annual & 1 & 1987 & 0.32 & 0.33 & Grootes and Stuiver (1997) \\
\hline 31 & GISP2 & -38.50 & 72.60 & Ice-core $\delta A r / N_{2}$ & Decadal & Annual & 1500 & 1993 & 0.71 & 0.53 & Kobashi et al. (2010) \\
\hline 32 & GRIP & -37.38 & 72.35 & Ice-core $\delta^{18} \mathrm{O}$ & Annual & Nov to Apr & 1 & 1979 & 0.07 & 0.02 & Vinther et al. (2010) \\
\hline 33 & Gotland & 19.00 & 57.00 & Tree-ring width & Annual & Summer & 1500 & 1987 & 0.18 & 0.09 & Esper et al. (2002a) \\
\hline 34 & Grotte di Ernesto & 11.66 & 45.98 & Speleothem microlayer & Annual & Annual & 1500 & 1987 & -0.00 & 0.08 & Frisia et al. (2003) \\
\hline 35 & Gulf of Alaska & -145.00 & 60.00 & Tree-ring width & Annual & Jan to Aug & 1500 & 2002 & 0.20 & 0.27 & D'Arrigo et al. (2006) \\
\hline 36 & Gulf of Taranto & 17.89 & 39.76 & Sea sediments & Annual-to-decadal & Fall & 1 & 1975 & 0.74 & 0.59 & Taricco et al. (2009) \\
\hline 37 & Hallet Lake & -146.20 & 61.50 & Lake sediments & Annual-to-decadal & Jun to Aug & 1 & 2005 & 0.26 & 0.33 & McKay et al. (2008) \\
\hline 38 & Haukadalsvatn & -21.37 & 65.03 & Lake sediments & Annual-to-decadal & Apr to May & 1 & 2003 & -0.18 & -0.17 & Geirsdóttir et al. (2009) \\
\hline 39 & Hesheng & 110.00 & 30.00 & Speleothem $\delta^{18} \mathrm{O}$ & Annual-to-decadal & Annual & 1500 & 1999 & 0.14 & 0.27 & Hu et al. (2008) \\
\hline 40 & Iceberg Lake & -142.95 & 60.78 & Varved lake sediments & Annual & May and Jun & 1500 & 1998 & 0.06 & 0.09 & Loso (2009) \\
\hline 41 & Idaho & -114.25 & 44.42 & Tree-ring width & Annual & Jul & 1500 & 1992 & 0.08 & 0.04 & Biondi et al. (1999) \\
\hline 42 & Indigirka & 148.15 & 70.53 & Tree-ring width & Annual & Jun to Jul & 1 & 1993 & 0.39 & 0.33 & Moberg et al. (2006) \\
\hline 43 & Jämtland & 13.30 & 63.10 & Tree-ring width & Annual & Jun to Aug & 1500 & 2000 & 0.46 & 0.39 & Linderholm and Gunnarson (2005) \\
\hline 44 & Jasper & -118.17 & 52.75 & Tree-ring width & Annual & Apr to Aug & 1500 & 1987 & 0.32 & 0.28 & Luckman et al. (1997) \\
\hline 45 & Karakorum & 74.99 & 36.37 & Tree-ring $\delta^{13} C$ & Annual & Jun and Jul & 1500 & 1993 & -0.15 & -0.15 & Treydte et al. (2009) \\
\hline 46 & Karakorum & 74.99 & 36.37 & Tree-ring width & Annual & Annual & 1500 & 1993 & -0.15 & -0.15 & Esper et al. (2002b) \\
\hline 47 & Korallgrottan & 14.16 & 64.89 & Speleothem $\delta^{18} \mathrm{O}$ & Decadal & Annual & 1 & 2005 & -0.30 & 0.36 & Sundqvist et al. (2010) \\
\hline 48 & Laanila & 27.30 & 68.50 & Tree-ring height inc. & Annual & Jun to Aug & 1500 & 2007 & 0.21 & 0.17 & Lindholm et al. (2011) \\
\hline 49 & Lake C2 & -77.54 & 82.47 & Varved lake sediments & Annual & Jun to Aug & 1 & 1987 & 0.21 & 0.22 & Lamoureux and Bradley (1996) \\
\hline 50 & Lake Silvaplana & 9.80 & 46.45 & Lake sediments & Annual-to-decadal & Jul & 1500 & 1995 & 0.69 & 0.44 & Larocque-Tobler et al. (2010) \\
\hline 51 & Lake of the Clouds & -71.25 & 44.25 & Pollen & Decadal & Jun to Aug & 1500 & 1965 & 0.60 & 0.53 & Gajewski (1988) \\
\hline 52 & Lomonosovfonna & 17.42 & 78.85 & Ice-core $\delta^{18} \mathrm{O}$ & Annual & Annual & 1500 & 1997 & 0.29 & 0.26 & Isaksson et al. (2005) \\
\hline 53 & Low Countries & 5.18 & 52.10 & Documentary & Annual & Annual & 1500 & 2000 & 0.65 & 0.76 & van Engelen et al. (2001) \\
\hline 54 & Lower Murray Lake & -69.32 & 81.21 & Varved lake sediments & Annual & Jun to Aug & 1 & 1969 & 0.28 & 0.30 & Cook et al. (2009) \\
\hline 55 & Mangazeja & 82.30 & 66.68 & Tree-ring density & Annual & Summer & 1500 & 1990 & 0.35 & 0.16 & Esper et al. (2002a) \\
\hline 56 & Mongolia & 98.93 & 48.30 & Tree-ring density & Annual & Apr to Oct & 262 & 1999 & 0.00 & 0.31 & D'Arrigo et al. (2001) \\
\hline 57 & NSIB (regional) & 100.00 & 72.00 & Tree-ring width & Annual & Summer & 1500 & 1991 & 0.39 & 0.32 & Briffa et al. (2001) \\
\hline 58 & NW North Alaska reg & -167.00 & 67.00 & Tree-ring density & Annual & Summer & 1500 & 2000 & 0.17 & 0.17 & D'Arrigo et al. (2006) \\
\hline 59 & North China & 113.00 & 40.00 & Documentary & Annual & Annual & 1500 & 1995 & 0.42 & 0.40 & Wang et al. (2001) \\
\hline 60 & North Icelandic Shelf & -19.30 & 66.30 & Sea sediments & Annual-to-decadal & Summer & 1 & 2001 & -0.34 & -0.11 & Sicre et al. (2011) \\
\hline 61 & North-Central China & 111.50 & 37.00 & Tree-ring width & Annual & Jun to Aug & 1500 & 2002 & 0.40 & 0.18 & Yi et al. (2012) \\
\hline 62 & NorthGRIP & -42.32 & 75.10 & Ice-core $\delta^{18} \mathrm{O}$ & Annual & Annual & 1 & 1995 & 0.20 & 0.15 & NGRIP members (2004) \\
\hline 63 & Northern Iceland & -19.30 & 66.30 & Sea sediments & Annual-to-decadal & Summer & 1500 & 2000 & 0.18 & 0.14 & Ran et al. (2011) \\
\hline 64 & Polar Urals & 65.75 & 66.83 & Tree-ring density & Annual & May to Sep & 1500 & 1990 & 0.43 & $\mathbf{0 . 3 3}$ & Esper et al. (2002a) \\
\hline 65 & Quebec & -70.00 & 53.00 & Tree-ring density & Annual & Summer & 1500 & 1947 & $\mathrm{NaN}$ & -0.09 & Esper et al. (2002a) \\
\hline 66 & Renland & -26.70 & 71.30 & Ice-core $\delta^{18} \mathrm{O}$ & Annual-to-decadal & Annual & 1 & 1980 & 0.69 & 0.59 & Vinther et al. (2008) \\
\hline 67 & Russian Plain & 45.00 & 55.00 & Multi-proxy & Decadal & Annual & 5 & 1995 & 0.32 & 0.86 & Sleptsov and Klimenko (2003) \\
\hline 68 & Severnaja & 106.00 & 81.00 & Lake sediments & Decadal & Jun to Aug & 1500 & 1979 & 0.03 & 0.09 & Bolshyanov and Makeev (1995) \\
\hline 69 & Seward Peninsula & -163.00 & 65.00 & Tree-ring density & Annual & Jun to Aug & 1500 & 2002 & 0.13 & -0.05 & D'Arrigo et al. (2005) \\
\hline
\end{tabular}


Table 1. Continued.

\begin{tabular}{|c|c|c|c|c|c|c|c|c|c|c|c|}
\hline \# & Site & Longitude & Latitude & Proxy type & Sample resolution & Season & First year & Last year & Corr1 & Corr2 & Reference \\
\hline 70 & ShiHua Cave & 116.23 & 39.54 & Speleothem microlayer & Annual & May to Aug & 1 & 1985 & -0.06 & 0.02 & Tan et al. (2003) \\
\hline 71 & Southern Colorado Plateau & -111.40 & 35.20 & Tree-ring width & Annual & Maximum summer temp & 1 & 1996 & 0.41 & 0.36 & Salzer and Kipfmueller (2005) \\
\hline 72 & Southern Greenland (regional) & -43.00 & 65.00 & Ice-core $\delta^{18} \mathrm{O}$ & Annual & Dec to Mar & 1500 & 1970 & 0.46 & 0.42 & Vinther et al. (2003) \\
\hline 73 & Southern Sierra Nevada & -118.90 & 36.90 & Tree-ring width & Annual & Jun to Aug & 1500 & 1988 & 0.21 & 0.22 & Graumlich (1993) \\
\hline 74 & Spanish Pyrenees & 1.00 & 42.50 & Tree-ring density & Annual & May to Sep & 1500 & 2005 & 0.57 & 0.66 & Büntgen et al. (2008) \\
\hline 75 & Sugan Lake & 93.90 & 38.85 & Lake sediments & Decadal & Winter & 15 & 1995 & -0.83 & 0.73 & Qiang et al. (2005) \\
\hline 76 & Svalbard & 17.00 & 78.00 & Ice melt layers & Annual & Jun to Aug & 1500 & 1985 & 0.00 & 0.05 & Tarussov (1992) \\
\hline 77 & Tarvagatay & 99.00 & 48.00 & Tree-ring density & Annual & Annual & 1500 & 1994 & 0.03 & 0.24 & Jacoby et al. (1996) \\
\hline 78 & Teletskoe Lake & 87.61 & 51.76 & Varved lake sediment & Annual & Annual & 1 & 2002 & 0.10 & 0.49 & Kalugin et al. (2009) \\
\hline 79 & Tibetan Plateau & 92.00 & 33.00 & Ice-core $\delta^{18} \mathrm{O}$ & Decadal & Annual & 5 & 1995 & 0.76 & 0.67 & Thompson et al. (2006) \\
\hline 80 & Tien Shen & 72.00 & 40.00 & Tree-ring width & Annual & Annual & 1500 & 1995 & -0.04 & -0.03 & Esper et al. (2003) \\
\hline 81 & Tokyo & 139.72 & 35.67 & Documentary & Annual & Winter & 1500 & 1975 & 0.65 & 0.72 & Gray (1974) \\
\hline 82 & Torneträsk & 19.80 & 68.31 & Tree-ring density & Annual & Apr to Aug & 1500 & 2004 & 0.63 & 0.58 & Grudd (2008) \\
\hline 83 & Torneträsk & 19.43 & 68.13 & Tree-ring width & Annual & Jun to Aug & 1 & 1993 & 0.54 & 0.50 & Grudd et al. (2002) \\
\hline 84 & Uamh an Tartair & -4.98 & 58.15 & Speleothem microlayer & Annual & Annual & 1500 & 1993 & 0.36 & 0.30 & Proctor et al. (2002) \\
\hline 85 & Usvyatskii Mokh & 32.00 & 56.00 & Pollen & Decadal & Annual & 1500 & 1995 & 0.41 & 0.62 & Klimenko et al. (2001) \\
\hline 86 & Vøring Plateau & 7.64 & 66.97 & Sea sediments & Decadal & Summer & 1 & 1995 & 0.22 & 0.31 & Andersson et al. (2010) \\
\hline 87 & WNA (regional) & -116.00 & 38.00 & Tree-ring width & Annual & Summer & 1500 & 1983 & 0.46 & 0.41 & Briffa et al. (2001) \\
\hline 88 & Yakutia & 147.00 & 69.50 & Tree-ring width & Annual & Summer & 1500 & 1994 & 0.18 & 0.12 & Hughes et al. (1999) \\
\hline 89 & Yamal & 69.17 & 66.92 & Tree-ring width & Annual & Jun to Jul & 1 & 1996 & 0.34 & 0.32 & Briffa (2000) \\
\hline 90 & Yangtze River Delta & 121.00 & 32.00 & Documentary & Decadal & Annual & 1500 & 1997 & 0.55 & 0.58 & Zhang et al. (2008) \\
\hline 91 & Yukon & -139.00 & 67.00 & Tree-ring density & Annual & Summer & 1500 & 2002 & 0.21 & -0.08 & D’Arrigo et al. (2006) \\
\hline
\end{tabular}

some inhomogeneities are observed. In particular, the oceans and the internal parts of the continents North America and Northeast Asia, as well as most of the interior of Asia, are sparsely covered, while some clustering is found in China, Europe, Greenland and to a lesser extent in western North America. However, the instrumental temperature record shows that the regions with good data coverage very well can capture both the trend and amplitude of temperature changes in the extra-tropical NH as a whole (Brohan et al., 2006, see also Sect. 5.3). The subset used for the two-millennia long reconstruction (blue symbols in Fig. 1) shows larger inhomogeneities; in particular North America and Central Europe have a sparser coverage. Only proxies that correlate significantly with the local temperature enter the LOC reconstruction, as explained in more detail in the next section. The bottom panel of Fig. 1 shows the geographical distribution of the 55 proxies ( 24 reaching back to at least $300 \mathrm{AD}$ ) that correlate significantly at the $1 \%$ level with the local temperatures in the period from $1880 \mathrm{AD}$ to the last year of each proxy. The correlations are given in column Corr 2 in Table 1. This reduced proxy set shows basically the same geographical inhomogeneities as described above for the full set of proxies.

All the proxies are shown as function of time for the period since $1500 \mathrm{AD}$ in Fig. 2. The proxies reaching back to at least $300 \mathrm{AD}$ are also shown for the full period in Fig. 3 . Where the proxies have consecutive annual values, these are connected. The annual resolved proxies are all complete except for Grotte di Ernesto (34, missing years 1681-1691, 1840-1857), Iceberg Lake (40, missing years 1642, 1825, 1834, 1867, 1899, 1957, 1982), and Burgundy (9, missing year 1978). These years have been filled in with linear interpolation. A few of the proxies display outliers, the most conspicuous being Teletskoe Lake (78), which shows a peak near $1600 \mathrm{AD}$. By removing the outliers and repeating the reconstructions, we have confirmed that the outliers have only marginal influence on the extra-tropical $\mathrm{NH}$ mean reconstructions.
Some of the proxy records we use here were among the 40 proxies used in the $1000 \mathrm{yr}$ long extra-tropical NH temperature reconstruction by Christiansen and Ljungqvist (2011), but many new records are also introduced. We have also utilized other versions of some records, either because they reach longer back in time or because newer versions of the records have become available. We have thus used the Avam-Taimyr regional tree-ring width chronology (Briffa et al., 2008) instead of the Taimyr tree-ring width chronology (Naurzbaev et al., 2002). The Avam-Taimyr record is a combination of the tree-ring width chronologies from Taimyr (Naurzbaev et al., 2002) and Bol'shoi Avam (Sidorova et al., 2007). The new Chesapeake Bay sea sediment record (Cronin et al., 2010) is used instead of the older one (Cronin et al., 2003).

We have tried to obtain a complete set of high-resolution temperature proxy records covering the last two millennia, fulfilling our data requirements stated above. However, several potentially useful historical documentary data sets from Europe cannot be used in this study since they do not have a sufficient overlap with the gridded instrumental data in HadCRUT3v (Brohan et al., 2006). Hence, the Central Europe temperature reconstruction by Dobrovolný et al. (2010), the Germany/Central Europe temperature reconstruction by Glaser and Riemann (2009), and the Stockholm winter/spring temperature reconstruction by Leijonhufvud et al. (2010) cannot be used here. However, the size of the proxy compilation used in this study is still larger than those used in all comparable studies, with the exceptions of Mann et al. (2008) and Mann et al. (2009).

\section{Reconstruction method}

The LOC reconstruction method is introduced and motivated in Christiansen (2011), and additional details and discussions can be found in Christiansen (2012), Tingley and Li (2012), 


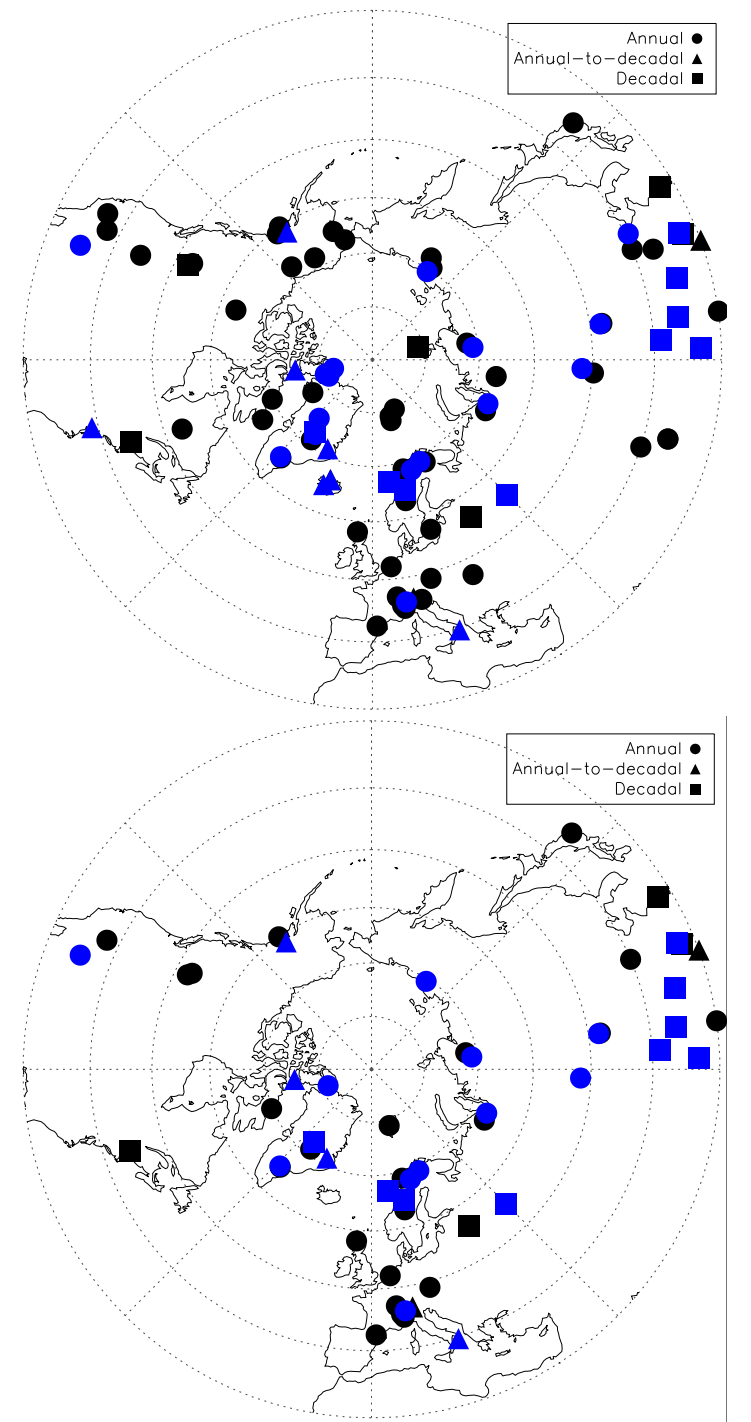

Fig. 1. The geographical locations of all the 91 proxies in Table 1 (top) and of those that correlate significantly with their local temperatures (from HadCRUT3v) in the period beginning in 1880 and lasting to the final year of each individual proxy (bottom). The resolution (annual, annual-to-decadal, decadal) is indicated with the symbols. Proxies that reach back to at least $300 \mathrm{AD}$ are indicated in blue.

and Christiansen and Ljungqvist (2011). Here we only give a brief description. The method requires calibration periods with simultaneous values of proxies and local temperatures. We assume that both proxies and temperatures are centered to zero in the calibration period. The LOC reconstruction method relates proxies to local temperatures and consists of three steps: (1) The proxies are screened and only proxies with a statistically significant relation to the local temperature in the calibration period are preserved. (2) Each of the proxies that passed the test is related linearly to the local temperature; $P=\lambda T+\xi$, where the noise $\xi$ and the local tem- perature $T$ are considered independent. It is important here that the proxy is chosen as the dependent variable. The regression coefficient $\lambda$ is determined from the data in the calibration period. The local temperature is then reconstructed by $T=P / \lambda$. (3) The reconstructed local temperatures are averaged to form the reconstructed large-scale (here extratropical $\mathrm{NH}$ ) mean temperature.

LOC avoids the underestimation of the low-frequency variability by using a forward model where the proxy is the dependent variable and by avoiding an explicit model for the spatial covariance structure of the temperature field. The forward model is the physical sound choice, as we expect proxies to respond to local temperature and not the other way around. If the local temperature was chosen as the dependent variable, the reconstructions would be biased towards zero. It is tempting to use a specific covariance model to infer temperatures in regions without proxies and then include these in the NH mean. However, the covariance structure calculated from the calibration period may not be relevant for the reconstruction period, which can lead to underestimation of variability. An extreme example is found in sea-level reconstructions (Christiansen et al., 2010).

Note that the calibration periods can be different for the different proxies. This feature was not used in previous LOC reconstructions (Christiansen, 2011; Christiansen and Ljungqvist, 2011) but will be exploited in the present work. Likewise, the local reconstructions may not necessarily be defined over identical periods and the $\mathrm{NH}$ mean will then be calculated from a different number of local reconstructions in different periods. This is only important for the two-millennia long reconstruction before $300 \mathrm{AD}$, as $\mathrm{Du}$ lan (21) and Mongolia (56) only reach back to $155 \mathrm{AD}$ and $262 \mathrm{AD}$, respectively.

In this paper we use gridded instrumental temperatures from HadCRUT3v (Brohan et al., 2006). This data-set is defined on a $5^{\circ} \times 5^{\circ}$ latitude-longitude grid and covers the period 1850-2011 AD. The data coverage varies strongly with time as can be seen from Fig. 4, which shows the average number of months with data in the different decades. Because data scarcity is strong in the 19th century, in particular over land outside Europe, we do not use instrumental temperatures from the earliest period; all our calibration periods begin in $1880 \mathrm{AD}$ or $1900 \mathrm{AD}$. As in Christiansen (2011) and Christiansen and Ljungqvist (2011), missing monthly data are filled with inverse distance interpolation. The annual means are then obtained to give the annually resolved temperature field, which is then interpolated to the positions of the proxies. These temperatures are in the following referred to as local temperatures. This is justified because the spatial decorrelation length for annual mean temperatures are several thousand kilometers (Jones et al., 1997). See Christiansen and Ljungqvist (2011) for a discussion of the impacts of the interpolation method. We do not detrend the local temperatures before using them for calibration. Keeping the trends is the usual choice in reconstruction 

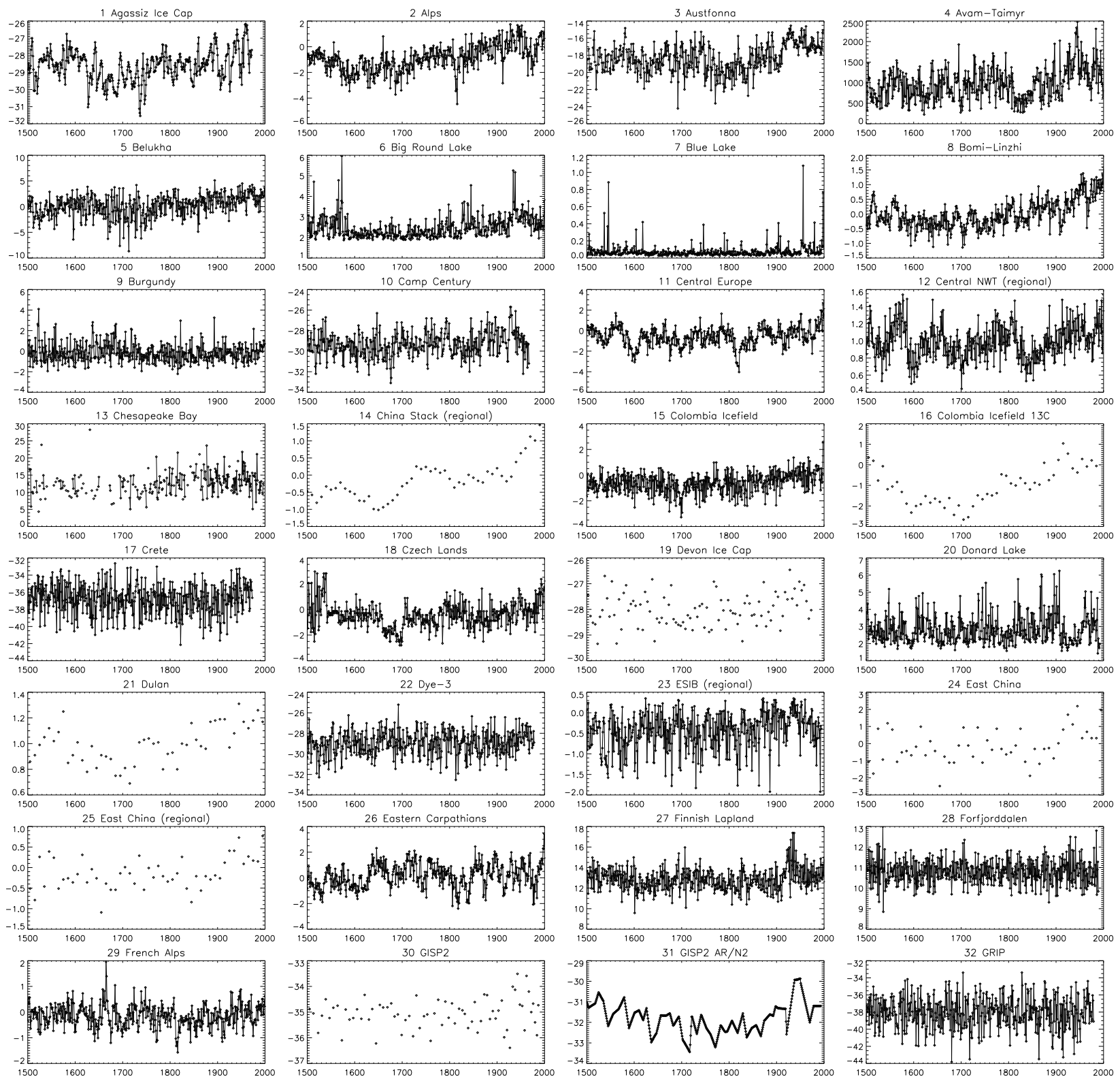

Fig. 2. The 91 proxies in Table 1 as function of time since 1500 AD. The proxies are in arbitrary units. Please refer to the original references listed in Table 1 for full details of each proxy record.

studies and only has a small effect on the LOC method (Christiansen, 2011).

When calibrating proxies of annual-to-decadal and decadal sampling, we have first linearly interpolated the proxies to annual values. To match the proxies, the local temperatures have been low-pass filtered with a cutoff at 5 or $10 \mathrm{yr}$ if the corresponding proxy is of annual-to-decadal or decadal resolution. The reconstructions are not sensitive to this procedure, as investigated in Christiansen and Ljungqvist (2011). Here and in the rest of the paper, low-pass filtering is performed with a Gaussian filter.
It is well known that most temperature proxy records primarily respond to a specific season (Jones and Bradley, 1992; Jones et al., 2003, 2009). Since we calibrate each proxy record to its local annual mean temperature, we may reject some proxy records that have a strong response to its optimal season. The correlation between different seasons is, however, usually high on decadal and longer timescales (Esper et al., 2002a; Brohan et al., 2006). For a discussion about possible changes in the annual cycle and their implications for temperature reconstructions, see also Jones et al. (2003). 

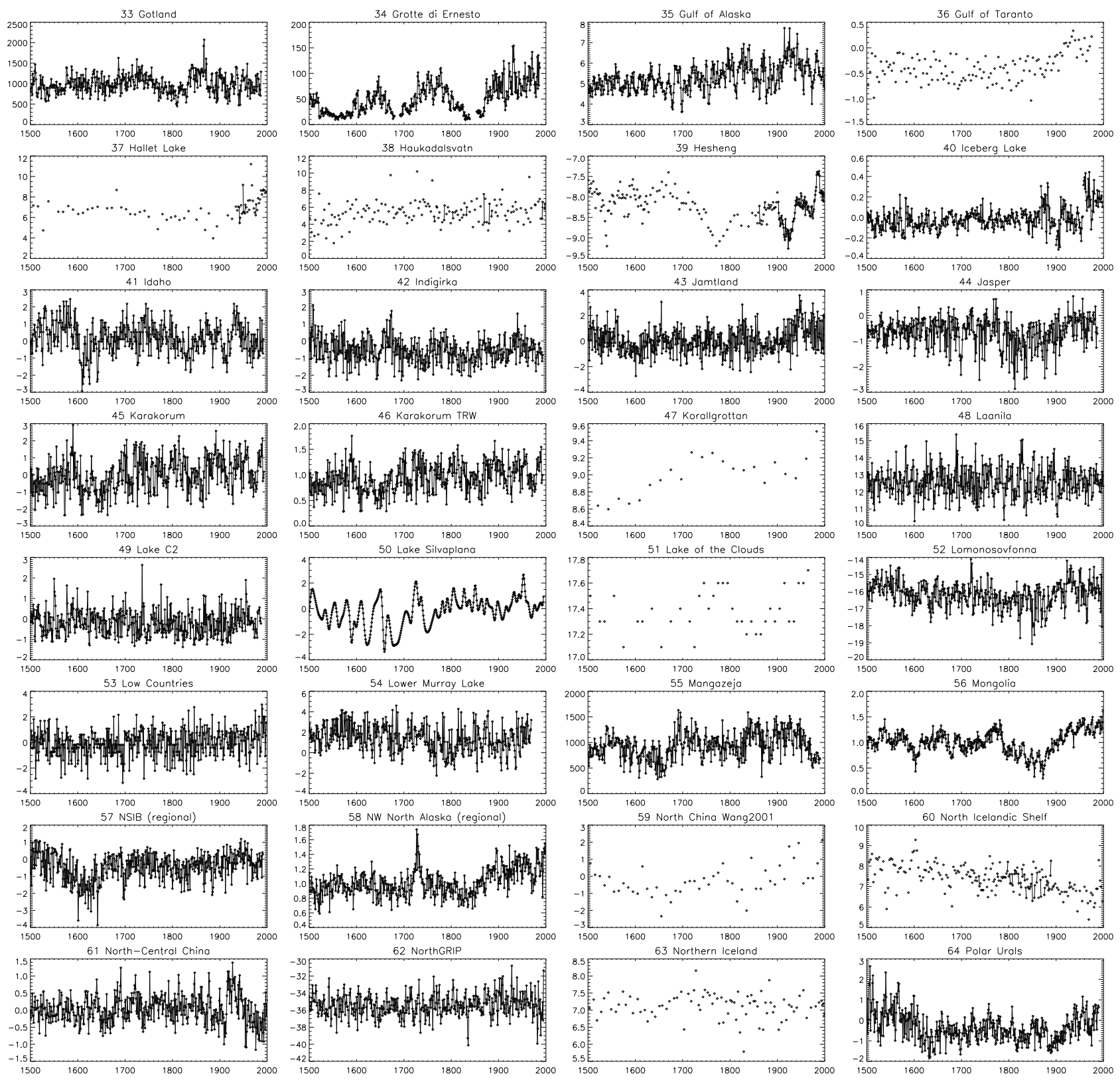

Fig. 2. Continued.

Confidence intervals are calculated by an ensemble pseudo-proxy method as in Christiansen and Ljungqvist (2011). This calculation is based on a 500-yr long forced experiment (Stendel et al., 2006) with the ECHAM4-OPYC3 climate model. The positions and the number of the pseudoproxies mimic those of the real proxies. The pseudoproxies are constructed by adding realistic noise to local temperatures, where the realistic noise is constructed to have the same autocorrelation spectra as the residuals between the real proxies and the corresponding local temperatures. See Christiansen et al. (2009) and Christiansen (2011) for more details about the ensemble pseudo-proxy method.
The ensemble pseudo-proxy method estimates both the variance and the bias of the error. In this respect it is superior to, e.g. the Bayesian approach (Tingley et al., 2012), which only provides the variance (see the discussion in Tingley and Li, 2012, and Christiansen, 2012). This point is in particular important for the reconstruction problem where the bias has been shown to be a serious problem (von Storch et al., 2004; Bürger and Cubasch, 2006; Zorita et al., 2007; Smerdon and Kaplan, 2007; Christiansen et al., 2009). However, it should be noted that confidence intervals obtained with the ensemble pseudo-proxy approach are probably too optimistic, as not all sources of stochasticity have 

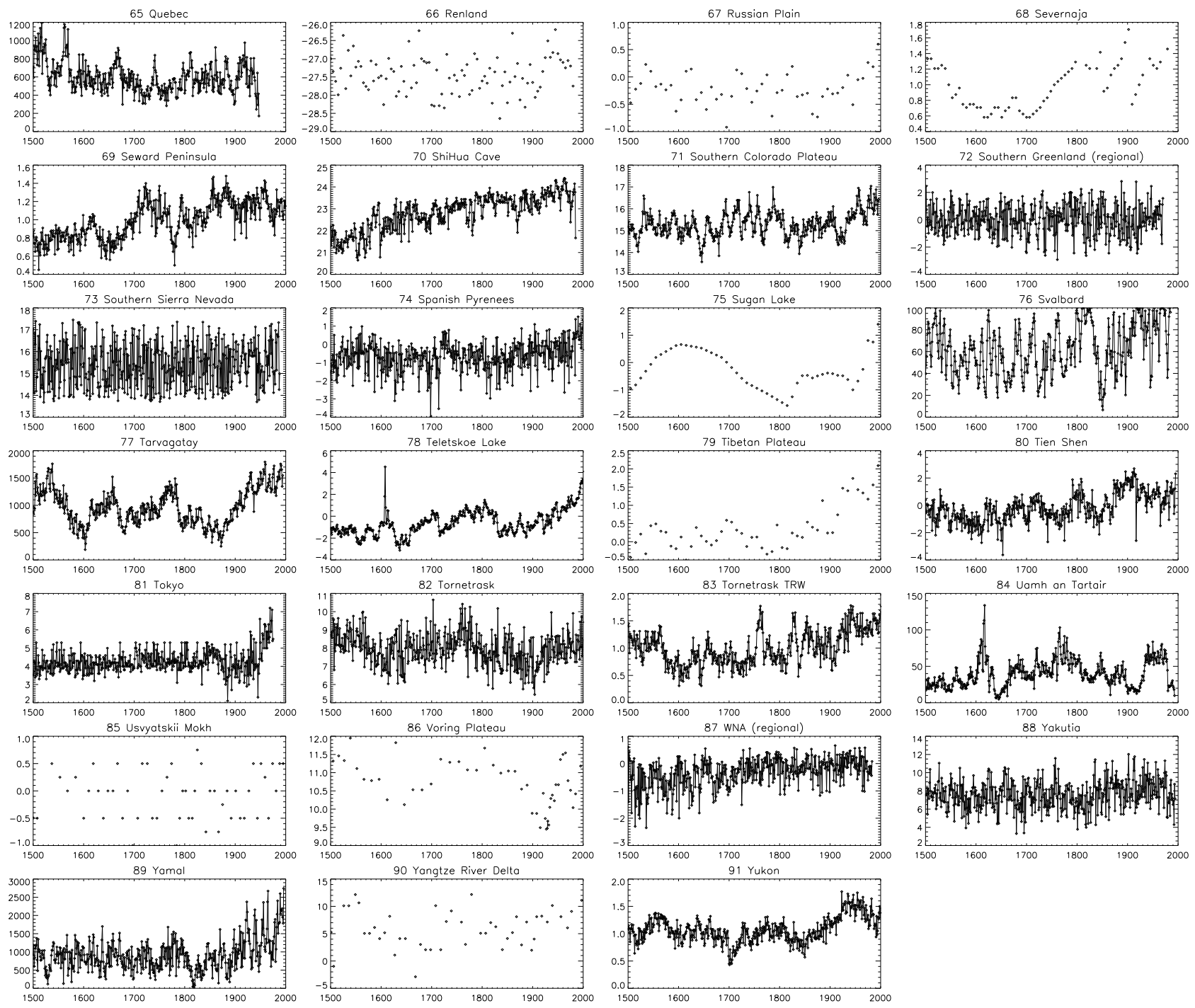

Fig. 2. Continued.

been included. See Christiansen and Ljungqvist (2011) for an example of including additional steps in the pseudo-proxy approach.

\section{Reconstructions}

We first consider the extra-tropical $\mathrm{NH}$ mean reconstructions. The two-millennia long reconstruction is discussed in Sect. 4.1 and the 500-yr long reconstruction in Sect. 4.2. For both periods we first present the reconstruction based on the calibration period 1880-1960 AD and then discuss the differences when compared to reconstructions based on other calibration periods. The robustness of the two-millennia long reconstruction is discussed in more detail in Sect. 5.1. The reconstructions calibrated in 1880-1960 AD are provided with confidence intervals estimated with the ensemble pseudo- proxy method. In Sect. 4.3 we consider the geographical distribution of the local reconstructions in selected periods.

\subsection{The NH two-millennia long reconstruction}

We first consider the two-millennia long reconstruction based on 32 proxies that reach back to at least $300 \mathrm{AD}$ (shaded rows in Table 1). With the calibration period 1880-1960 AD, 16 proxies have positive correlations with the local temperature and are significantly related to this temperature at the $p=0.01$ level, as estimated with a $t$-test. The correlations are shown in Table 1 (column denoted Corr1) and significant values are boldfaced. The correlations between the 16 proxies and their local temperatures fall in the interval $0.32-0.92$ with mean/median of $0.52 / 0.41$. Assuming that the proxies and local temperatures are without serial correlations (which is obviously not true, see 

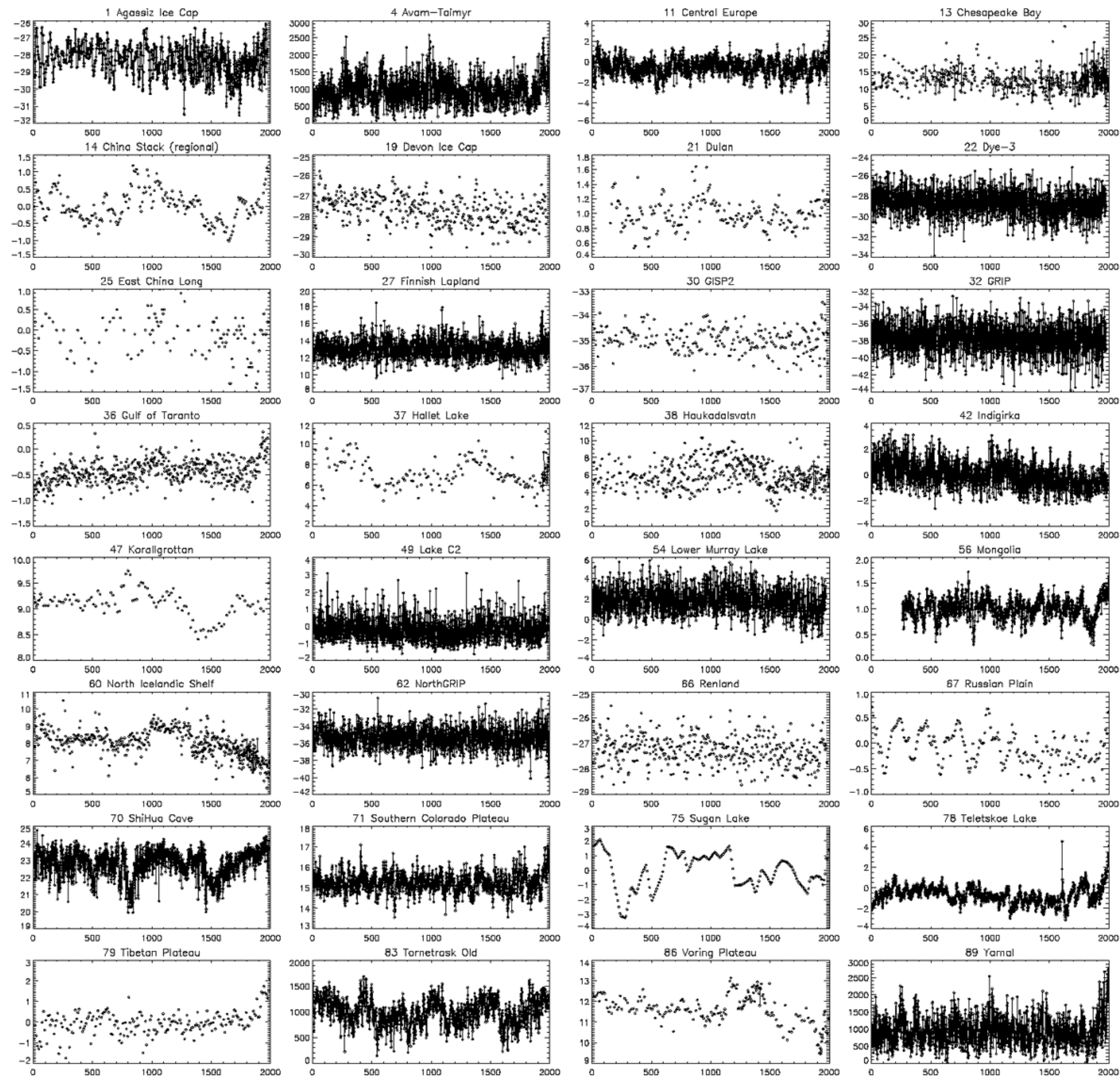

Fig. 3. The 32 proxies gray-shaded in Table 1 reaching back to at least $300 \mathrm{AD}$ as function of time. The proxies are in arbitrary units. Please refer to the original references listed in Table 1 for full details of each proxy record.

Christiansen and Ljungqvist (2011) for a discussion of the effects of using a more strict test), choosing $p=0.01$ corresponds to a cut-off correlation of 0.29 . From these 16 proxies the local temperatures are reconstructed, and inspection of the 50-yr smoothed versions (applying a Gaussian filter a with standard deviation of $25 \mathrm{yr}$ ) shows that they all fall within reasonable limits with anomalies of no more than $\pm 4^{\circ} \mathrm{C}$. The extra-tropical $\mathrm{NH}$ mean temperature obtained as the simple mean of these local reconstructed temperatures is shown in Fig. 5.

Confidence intervals of the 50-yr smoothed values are superimposed on the reconstruction in Fig. 5. These confi- dence intervals are calculated by an ensemble pseudo-proxy approach as described in Sect. 3, mimicking the conditions of the real-world reconstruction. We see that the LOC reconstruction only has small bias and that the $95 \%$ confidence interval has a width of $0.6^{\circ} \mathrm{C}$. This makes anomalies in 1500-1900 AD (LIA) and 950-1050 AD (MWP) significantly different from zero, while the temperatures before $900 \mathrm{AD}$ do not show any significant deviations from the mean temperature in the calibration period 1880-1960 AD.

In Fig. 6 the new reconstruction is compared to some previous temperature reconstructions published subsequently to the IPCC Fourth Assessment Report 

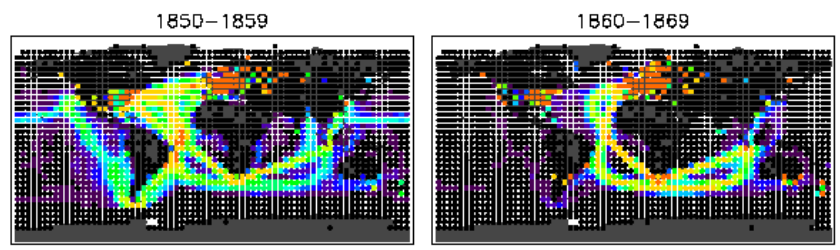

$1890-1899$

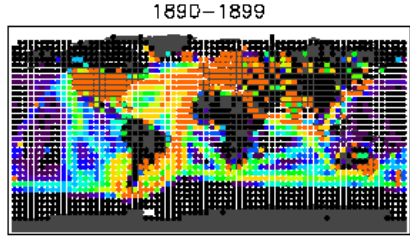

1930-1939

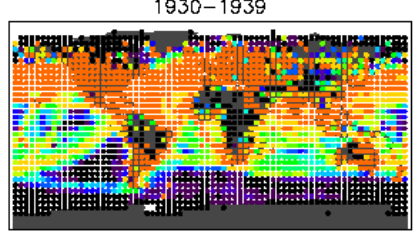

$1970-1979$

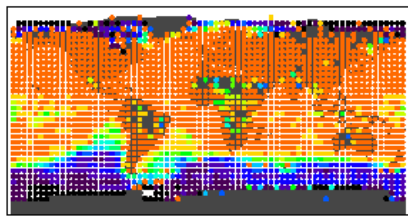

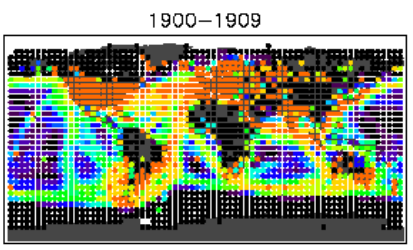

1940-1949

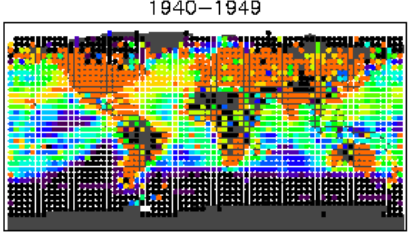

1980-1989

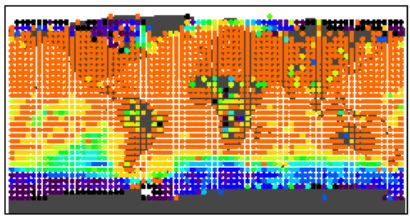

$1870-1879$

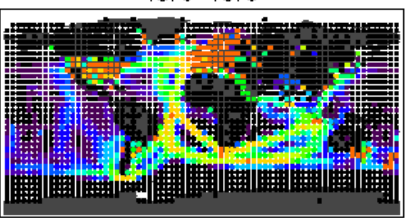

1910-1919

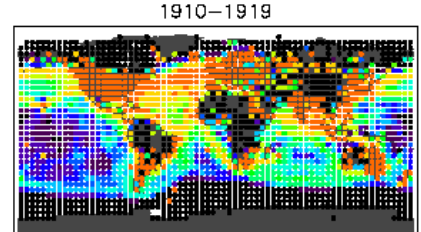

1950-1959

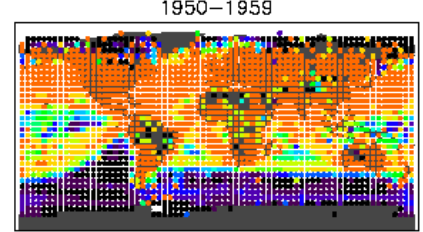

1990-1999

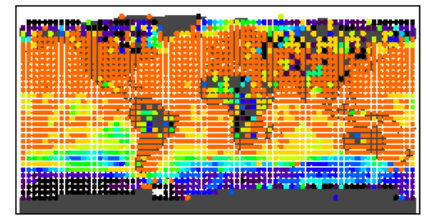

$1880-1889$

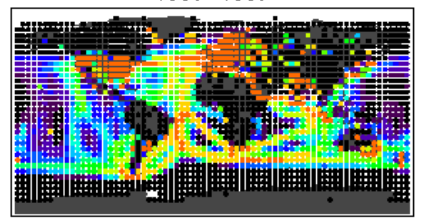

$1920-1929$

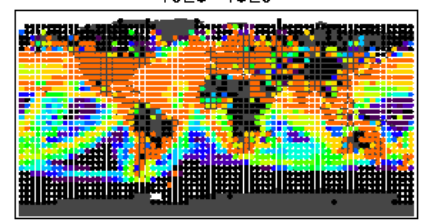

1960-1969

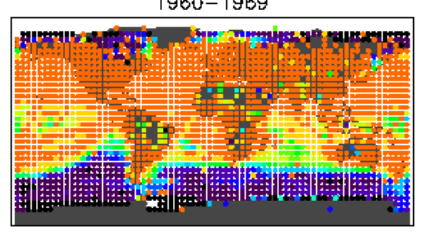

$2000-2009$

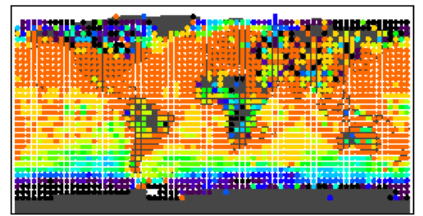

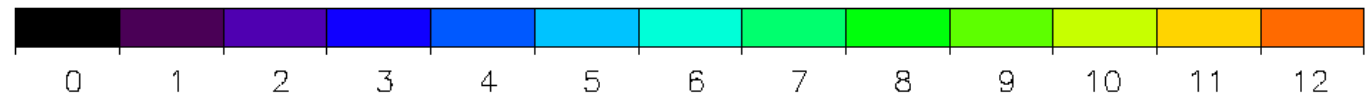

Fig. 4. Average number of months per year with data in HadCRUT3v in different decades.

(Solomon et al., 2007): the extra-tropical $\mathrm{NH}\left(30-90^{\circ} \mathrm{N}\right)$ CH-blend Dark Ages version of Hegerl et al. (2007), the extra-tropical $\mathrm{NH} \quad\left(30-90^{\circ} \mathrm{N}\right)$ reconstruction by Ljungqvist (2010), the global reconstruction by Loehle and McCulloch (2008), the $\mathrm{NH}\left(0-90^{\circ} \mathrm{N}\right)$ errorin-variables version of Mann et al. (2008), the $\mathrm{NH}$ $\left(0-90^{\circ} \mathrm{N}\right)$ reconstruction of Mann et al. (2009), and the global borehole temperature estimates for the last $500 \mathrm{yr}$ by Huang et al. (2008). The LOC reconstruction of Christiansen and Ljungqvist (2011) is also included. All reconstructions are 50-yr smoothed and centered to zero mean in 1880-1960 AD. Generally we note from Fig. 6 that the LOC reconstructions show larger low-frequency variability than previous reconstructions. In particular the period 1600-1850 AD is colder in the LOC reconstructions than in the other reconstructions. In fact, the temperature anomaly in all the other reconstructions fall outside the $95 \%$ confidence interval around the new LOC reconstruction. An exception is the borehole temperature reconstruction of Huang et al. (2008), which around its minimum around $1700 \mathrm{AD}$ reaches values comparable to those of the LOC reconstructions.
The coldest period in the new LOC reconstruction is ca. 1580-1720 AD where the 50-yr smoothed temperature anomaly reaches $-1.0^{\circ} \mathrm{C}$ relative to $1880-1960 \mathrm{AD}$. This is in agreement with the millennia long LOC reconstruction of Christiansen and Ljungqvist (2011) based on 40 proxies, of which 23 passed the $t$-test. The two reconstructions are in fact quite alike regarding the second millennium both in shape and amplitude, the major difference being that the current reconstruction is around $0.2^{\circ} \mathrm{C}$ colder in the period $1100-1550$ AD. However, this difference is in general within the confidence intervals, which are a bit narrower for the reconstruction of Christiansen and Ljungqvist (2011) than for those of the new LOC reconstruction. Also note that the reconstructions are not totally independent, as a subset of the proxies is used in both studies as discussed in Sect. 2.

The cold period $1500-1900 \mathrm{AD}$ is also a prominent feature of previous reconstructions, as seen in Fig. 6, but the LOC reconstructions give colder temperatures than other reconstructions. A very distinct warm peak occurs in the new reconstruction in the second half of the 10th century with temperatures up to $0.6^{\circ} \mathrm{C}$ warmer than the calibration period 1880-1960 $\mathrm{AD}$, equalling the temperatures of the 


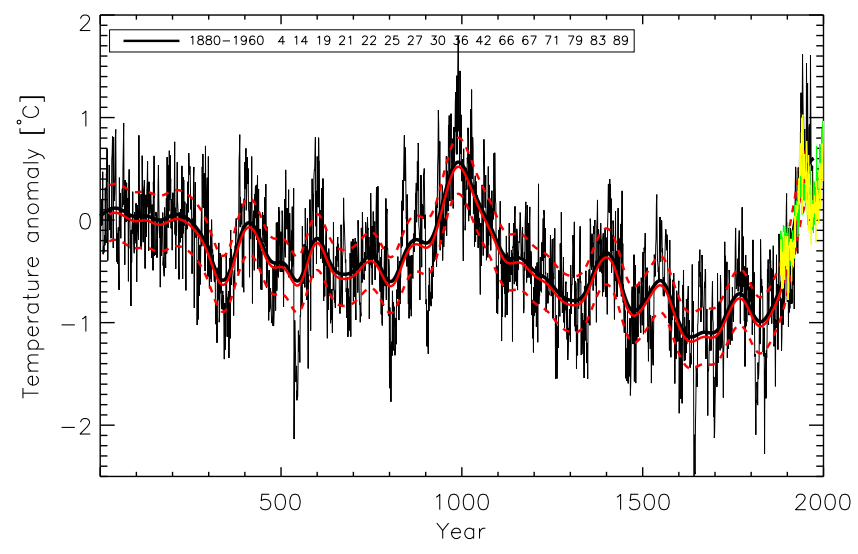

Fig. 5. Reconstruction of the extra-tropical NH mean temperature $\left({ }^{\circ} \mathrm{C}\right)$ based on the gray-shaded proxies in Table 1 reaching back to at least 300 AD. Calibration period 1880-1960 AD. Only proxies with positive correlations and a $p$-value less than 0.01 are used. The included proxies are given in the legend. Thin curves are annual values; thick curves are 50-yr smoothed. Red curves show bias and confidence intervals for the 50 -yr smoothed values. From ensemble pseudo-proxy studies mimicking the reconstructions, we have calculated the distribution of 50-yr smoothed differences between reconstructions and target. The biases and the upper and lower $2.5 \%$ quantiles are calculated from these distributions. In the figure the biases (full red curves) have been added to the real-world reconstructions. Likewise, the upper and lower quantiles have been added to the real-world reconstructions (dashed red curves). The green curve shows the observed extra-tropical $\left(>30^{\circ} \mathrm{N}\right)$ annual mean temperature. The yellow curve show the temperature average over grid-cells with accepted proxies. Both curves have been centered to zero in 1880-1960 AD.

mid-20th century. This warm event represents the climax of the MWP. Note that the extra-tropical NH mean temperature from HadCRUT3v in $1880-1960 \mathrm{AD}$ is $0.23^{\circ} \mathrm{C}$ colder than in the often used standard climate period 1961-1990 AD. For the complete $\mathrm{NH}$ mean temperature, the corresponding number is $0.22^{\circ} \mathrm{C}$. The MWP in the LOC reconstruction seems somewhat shorter and more well-defined than in previous reconstructions (Fig. 6) mainly because the LOC reconstruction is colder in the centuries before and after the 10th and 11 th centuries.

We have repeated the reconstruction with different calibration periods. As mentioned previously the LOC method allows different calibration periods for the different proxies. Using a calibration period beginning in $1880 \mathrm{AD}$ and lasting to the end of each proxy (see Table 1), 24 proxies pass the $t$-test at the $1 \%$ level. This set of proxies includes the 16 proxies that passed the test with the calibration period 1880 1960 AD, and eight new proxies. From the correlations listed in Table 1, we see that the larger number of proxies are due mainly to an increase in the correlations with the new (mainly longer) calibration periods and not due to a decrease of the cut-off frequency related to these longer calibration periods.

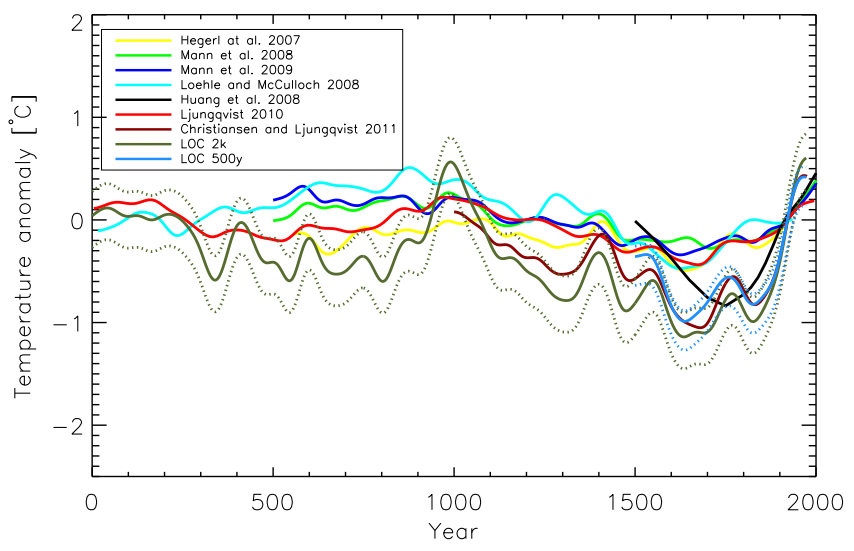

Fig. 6. Some previous temperature reconstructions, (Hegerl et al., 2007; Loehle and McCulloch, 2008; Huang et al., 2008; Mann et al., 2008, 2009; Ljungqvist, 2010; Christiansen and Ljungqvist, 2011) published subsequently to the IPCC Fourth Assessment Report (Solomon et al., 2007) shown together with the LOC reconstructions of the present paper. All reconstructions are centered to zero mean in the $1880-1960 \mathrm{AD}$ period and have been $50-\mathrm{yr}$ smoothed with a Gaussian filter. The confidence intervals of the LOC reconstructions of the present paper (from Figs. 5 and 8) are also shown (dashed curves).

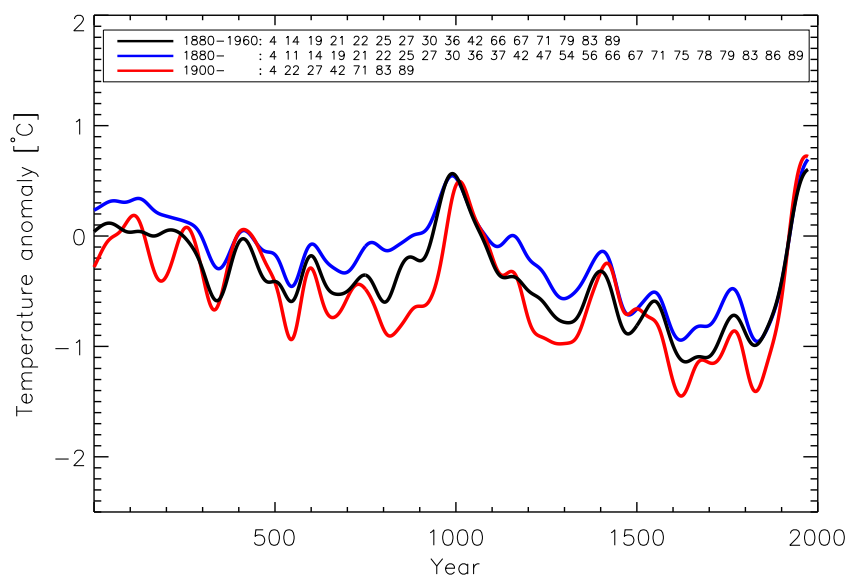

Fig. 7. Reconstruction of the extra-tropical NH mean temperature $\left({ }^{\circ} \mathrm{C}\right)$ based on the gray-shaded proxies in Table 1 reaching back to at least 300 AD. Different calibration periods: $1880-1960$ AD as in Fig. 5, 1880 to the final year of each individual proxy, and 1900 to the final year of each individual proxy. See Table 1 for the last year of the individual proxies. Only proxies with positive correlations and a $p$-value less than 0.01 are used. The included proxies are given in the legend. All reconstructions are 50-yr smoothed and centered to zero mean in 1880-1960 AD.

For a few of the proxies, the correlations change drastically with the change in the calibration period (e.g. China Stack, 14), making them less reliable. The correlations now fall in the interval $0.28-0.90$ with a mean/median of $0.46 / 0.41$.

From these proxies the local temperatures are reconstructed and adjusted to zero mean in the reference period 


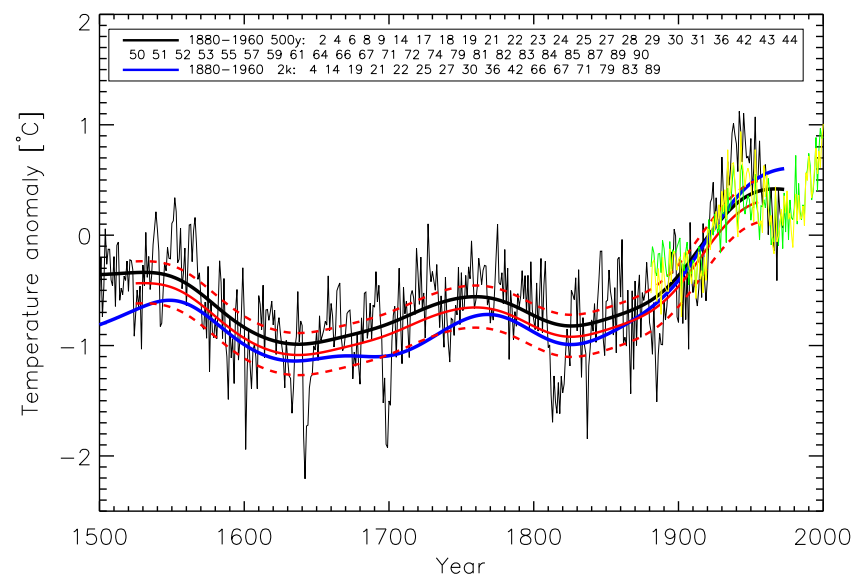

Fig. 8. Reconstructions of the extra-tropical NH mean temperature $\left({ }^{\circ} \mathrm{C}\right)$ based on all the proxies in Table 1 . Calibration period 1880-1960 AD. Only proxies with positive correlations and a $p$ value less than 0.01 are used. The included proxies are given in the legend. Thin curves are annual values; thick curves are 50-yr smoothed. The two-millennia long reconstruction from Fig. 5 is shown in blue. Red curves show bias and confidence intervals for the 50-yr smoothed values (see caption to Fig. 5). The green curve shows the observed extra-tropical $\left(>30^{\circ} \mathrm{N}\right)$ annual mean temperature. The yellow curve shows the temperature average over gridcells with accepted proxies. Both curves have been centered to zero in 1880-1960 AD.

$1880-1960 \mathrm{AD}$ (this step is necessary because of the different calibration periods). Figure 7 (blue curve) shows the $\mathrm{NH}$ mean based on these 24 local reconstructions. A similar reconstruction with the calibration period beginning in $1900 \mathrm{AD}$ is also included (red curve). With this choice of calibration periods, 21 proxies pass the test and the correlations now fall in the interval $0.26-0.89$ with a mean/median of $0.48 / 0.45$. We find only small differences between the three $\mathrm{NH}$ mean reconstructions. This is in agreement with Christiansen and Ljungqvist (2011) that showed that the LOC reconstruction method is fairly robust with respect to changes in, e.g. the calibration period.

\subsection{The NH 500-yr long reconstruction}

All 91 proxies in Table 1 have been considered in a reconstruction of the period since $1500 \mathrm{AD}$. Using a calibration period $1880-1960 \mathrm{AD}$, we find that 47 proxies pass the $t$ test at the $1 \%$ level. The correlations between these accepted proxies and their local temperatures fall in the interval $0.29-0.92$, with a mean/median of $0.49 / 0.42$. The resulting extra-tropical $\mathrm{NH}$ mean reconstruction is shown in Fig. 8 (black curve) and also included in the comparison in Fig. 6. Again we find a cold 17th century with temperatures around $-1{ }^{\circ} \mathrm{C}$ below the $1880-1960 \mathrm{AD}$ level, in agreement with the millennia long reconstruction of Christiansen and Ljungqvist (2011). Good agreement is also found when compared to the reconstruction reaching back to $1 \mathrm{AD}$ from the previous section (also shown in Fig. 8, blue curve). From Fig. 6 we see that these reconstructions have ovelapping confidence intervals in the period since $1500 \mathrm{AD}$.

Actually, the confidence intervals calculated with the ensemble pseudo-proxy approach again show only a small bias. The width of the $95 \%$ confidence interval is now $0.4{ }^{\circ} \mathrm{C}$, making the whole period $1500-1900$ AD significantly colder than the calibration period. The confidence interval is more narrow than that of the two-millennia long reconstruction, as should be expected because of the larger number of proxies. Compared to this reconstruction based on 32 proxies (16 accepted), we find that the amplitude of the high-frequency variability in the reconstruction based on 91 proxies (47 accepted) has decreased as expected due to the larger number of proxies (Christiansen, 2011). This decrease is around $15 \%$ when the high-frequency variability is measured as the variance of the 50-yr high-passed reconstructions.

We have again repeated the reconstruction with different calibration periods lasting to the end of each proxy and beginning in $1880 \mathrm{AD}$ or $1900 \mathrm{AD}$. For these calibration intervals, 55 and 47 proxies pass the $t$-test, respectively; and the correlations fall in the intervals $0.24-0.90$ and $0.26-$ 0.89 with means/medians of $0.46 / 0.41$ and $0.48 / 0.45$, respectively. The resulting $\mathrm{NH}$ mean reconstructions strongly resemble the reconstruction based on the calibration period 1880-1960 AD (Fig. 9), with differences falling inside the $95 \%$ confidence interval, as shown in Fig. 8. The largest differences are found in the level of the cold minimum in the first half of the 19th century. In comparison, very small differences are found in the cold minimum in the 17 th century.

\subsection{The geographical distribution}

As we have seen, the LOC method gives local reconstructions at the positions of the proxies (but not elsewhere in contrast to field reconstruction methods). LOC is designed to produce a good large-scale (e.g. $\mathrm{NH}$ ) low-frequency mean and relies on both temporal and spatial averaging to reduce the high-frequency noise (see also Sect. 5.2). However, LOC only determines the amplitude of the local temperature anomalies. The sign is determined by the proxies themselves. Negative values of a local reconstruction in a given period are a consequence of the proxy having a smaller value in this period than in the calibration (reference) period.

We have estimated the confidence intervals of $100-\mathrm{yr}$ means of the local reconstructions with the ensemble pseudoproxy approach described previously. Compared to the confidence intervals of the extra-tropical $\mathrm{NH}$ mean, we do not profit from spatial averaging but, on the other hand, we do not have the complication of the unknown spatial covariance. The widths of these confidence intervals on the local reconstructions vary a lot as they depend, among other factors, on the correlation between the proxy and the local temperature 


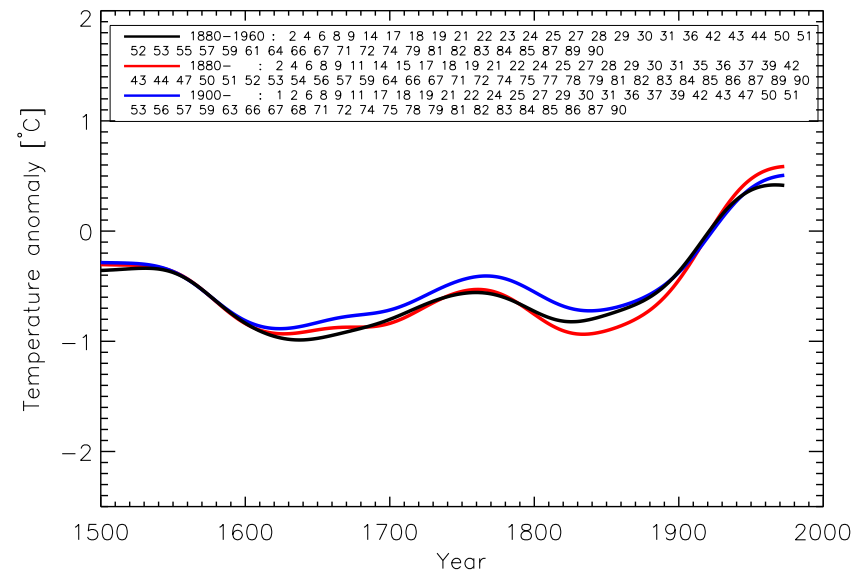

Fig. 9. Reconstructions of the extra-tropical NH mean temperature $\left({ }^{\circ} \mathrm{C}\right)$ based on all the proxies in Table 1. Different calibration periods: 1880-1960 AD as in Fig. 8, 1880 to the final year of each individual proxy, and 1900 to the final year of each individual proxy. See Table 1 for the last year of the individual proxies. Only proxies with positive correlations and a $p$-value less than 0.01 are used. The included proxies are given in the legend. All reconstructions are 50-yr smoothed and centered to zero mean in 1880-1960 AD.

and on the autocorrelation structure of the proxy. As LOC takes the proxy as the dependent variable, the confidence intervals of the local reconstructions decrease substantially when the correlation between the proxy and the local temperature grows (Christiansen, 2012). With strong serial correlations in the proxy, the correlation between local temperature and the proxy is badly constrained due to the reduced number of degrees of freedom. The latter factor makes the confidence intervals of the annually-to-decadally and decadally resolved proxies particularly wide. We find that when all proxies that pass the $t$-test at the $1 \%$ level are considered, the width of the $95 \%$ confidence intervals varies from less than $0.5^{\circ} \mathrm{C}$ to more than $2{ }^{\circ} \mathrm{C}$.

With these considerations and limitations in mind, we discuss some of the spatial features found in century long temporal means. We consider three periods: the two cold peaks of the LIA, 1600-1699 AD and 1800-1899 AD; and the peak of the MWP, 950-1049 AD. The geographical distributions of the mean anomalies are shown in Fig. 10, where the anomalies in the LIA are taken from the 500-yr long reconstruction and the anomalies in the MWP are from the two-millennia long reconstruction. This figure also includes histograms of the local temperature anomalies.

For the periods $1600-1699 \mathrm{AD}$ and $1800-1899 \mathrm{AD}$, the local anomalies have means of -0.91 and $-0.76^{\circ} \mathrm{C}$, respectively. The geographical distributions of temperature anomalies in the two periods are almost identical and are relatively homogeneous, with cold anomalies almost everywhere. Of the 47 local reconstructions, 8 in 1600-1699 AD and 3 in 1800-1899 AD show warm anomalies. In some re- gions, nearby local reconstructions disagree. This is particularly conspicuous in Greenland, with Crete (17) and Southern Greenland (72) showing warming and Dye-3 (22) and GISP2 $(30,31)$ showing cooling in 1600-1699 AD.

The geographical distribution of temperature anomalies in the MWP shows larger inhomogeneities than observed in the LIA. For the period $950-1049 \mathrm{AD}$ the mean is $0.49^{\circ} \mathrm{C}$, but only 9 out of 16 local reconstructions show warm anomalies, although the cold anomalies are weak. In comparison, the two-millennia long reconstruction has only one proxy, with warm anomaly in each of the periods 1600-1699 AD and 1800-1899 AD. Note that all local reconstructions for Greenland agree on warm anomalies in the MWP

As mentioned, the warm local temperature anomalies in the periods 1600-1699 AD and 1800-1899 AD are both weak and few, whereas the cold anomalies in 950-1049 AD are more abundant. However, the strengths of the spatial variances in the three periods cannot be directly compared from the local temperature anomalies relative to the calibration period. This is because the temperature anomalies are centered to zero in the calibration period and the spatial variance will therefore be zero in this period and suppressed in overlapping or nearby periods. Centering the two-millennia long reconstruction to zero in the whole period, we find the spatial standard deviations 1.01, 0.69, and $0.64{ }^{\circ} \mathrm{C}$ in $950-1049,1600-1699$ and $1800-1899 \mathrm{AD}$, respectively. The standard deviations of all 100-yr means are shown in Fig. 11 as a function of the central year in the period. Values higher than those found for 950-1049 AD are only found in the 9th century, while the values for 1600 1699 AD and 1800-1899 AD are not unusual. However, applying a F-variance test shows that the standard deviation of 950-1049 AD is only significantly different from other periods when the standard deviation of these periods is less than $0.65^{\circ} \mathrm{C}$. Therefore, this analysis gives only weak indications that the MWP was unusually spatially variable. This is in accordance with results from Esper and Frank (2009) and Ljungqvist et al. (2012) (see also Sect. 6).

\section{Robustness, spatial averaging, and validation}

In this section we study the robustness of the low-frequency behaviour of LOC, consider a possible limitation of pseudoproxy experiments, and discuss issues relating to the validation of the LOC reconstructions.

\subsection{Robustness}

Christiansen and Ljungqvist (2011) showed that their realworld reconstruction based on 40 proxies was robust to changes in, e.g. the calibration interval, the screening method, and the procedure for calculating the spatial average. For both the two-millennia long reconstruction and the 500-yr long reconstruction of the present study we 

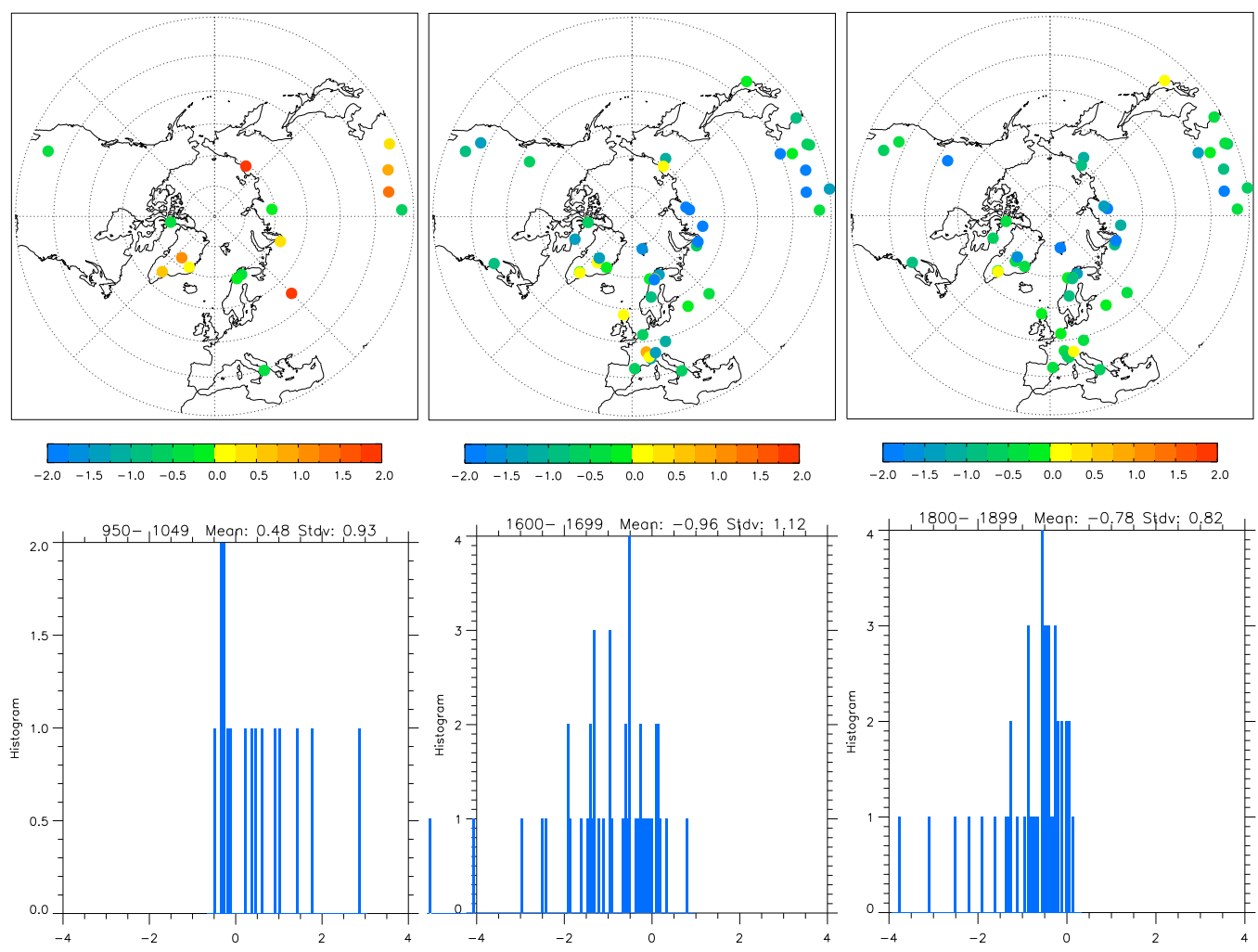

Fig. 10. Top: the geographical distributions of temperature anomalies in the period 950-1049 AD (left, two-millennia long reconstruction), 1600-1699 AD (middle, 500-yr long reconstruction), and 1800-1899 AD (right, 500-yr long reconstruction). For clarity temperatures have been cut off at -2 and $2{ }^{\circ} \mathrm{C}$. Bottom: the corresponding histograms. Calibration period is $1880-1960$ AD and anomalies are shown relative to this period.

find similar results regarding the robustness to those of Christiansen and Ljungqvist (2011). In the previous section we presented the result for different calibration intervals, see Figs. 7 and 9. In the following we demonstrate further the robustness of the two-millennia long reconstruction based on the calibration period 1880-1960 AD. In general the different reconstructions presented below agree within the confidence intervals (where widths increase with decreasing numbers of proxies).

Christiansen and Ljungqvist (2011) investigated three different alternatives to the simple averaging used in this paper to obtain the extra-tropical $\mathrm{NH}$ mean from the local reconstructions and found only minor differences. One alternative way to calculate the mean is to weight the local reconstructions according to the correlation between the proxy and the local temperature. The reconstruction calculated with this averaging procedure is shown with the blue curve in Fig. 12. Only small differences are found in the low-frequency variability when compared to the reconstruction based on the simple mean (black curve).

Of the 32 proxies considered for the two-millennia long reconstruction, $13 / 19$ are positioned south/north of $60^{\circ} \mathrm{N}$. Of the 16 proxies that pass the screening, these numbers are $7 / 9$. The reconstructions based only on the $7 / 9$ proxies south/north of $60^{\circ} \mathrm{N}$ are shown with red and light blue curves in Fig. 12. We find only moderate changes in the variability on the lowest frequencies, while more variability has been introduced to the high-frequencies, as expected from the small number of proxies.

Of the 16 proxies that pass the screening, 7 are of annual resolution and 9 are of annual-to-decadal or decadal resolution. Reconstructions based on these two sub-sets are shown in Fig. 12 with green and yellow curves. The lowfrequency variability of these reconstructions are in general quite similar, with the reconstruction based on the proxies of annual resolution being somewhat colder in the period since 500 AD.

In Christiansen and Ljungqvist (2011) the low-pass filtering of the extra-tropical mean reconstructions was performed with a 50-yr moving average filter. In the present paper we have used the more commonly used Gaussian filter (with a standard deviation of $25 \mathrm{yr}$ ). For comparison we have shown the reconstruction smoothed with the moving average filter in Fig. 12 (black dashed curve). As expected, the differences between the two filters are small, with the Gaussian filter giving the softest smoothing. 


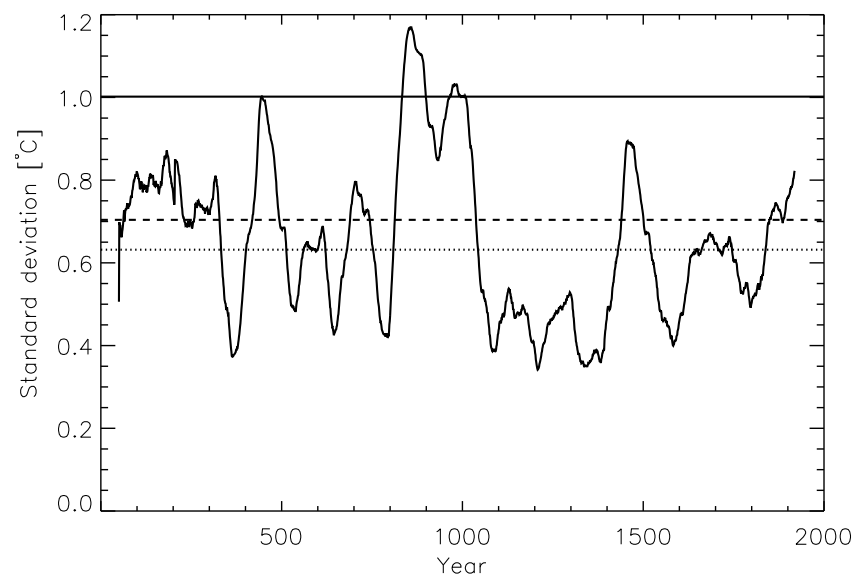

Fig. 11. The spatial standard deviation of 100-yr means of the local reconstructions (two-millennia long reconstruction, calibration period 1880-1960 AD). The horizontal axis indicates the central years of the $100-\mathrm{yr}$ periods. Horizontal lines indicate the standard deviation of the periods 950-1049 AD (solid line), 1600-1699 (dotted line), and 1800-1899 (dashed line).

\subsection{Spatial averaging}

Based on an ensemble pseudo-proxy method, Christiansen (2011) confirmed that LOC reconstructs low-frequency variability well, and both Christiansen and Ljungqvist (2011) and the present paper provide confidence intervals based on a similar pseudo-proxy method. However, pseudo-proxies are generated by degrading the local temperature by adding noise and therefore include assumptions about the temporal structure of the noise (Moberg, 2012; Christiansen and Ljungqvist, 2012).

Christiansen and Ljungqvist (2012) discuss how the cutoff between exaggerated high-frequency variability and well reconstructed low-frequency variability depends on the degree of auto-correlation in the noise. It is shown with both theoretical arguments and numerical experiments how averaging (temporal and/or spatial) leads to a reduction in the noise for the reconstructions. Note, e.g. as discussed in Sect. 4.2, the difference in the high-frequency noise between the reconstructions in Figs. 5 and 8, including 16 and 47 proxies, respectively. In Christiansen and Ljungqvist (2012) it is furthermore demonstrated that with observed values of the auto-correlations in the noise, the 50-yr smoothed values are well reconstructed with only a small amount of additive noise.

In the present paper as well as in Christiansen (2011) and Christiansen and Ljungqvist (2011), the noise was calculated so that it had the same autocorrelation spectra as the residuals between the real proxies and the corresponding local temperatures (see Christiansen et al., 2009). As these autocorrelation spectra are calculated from timeseries of limited length ( $\sim 80 \mathrm{yr}$ ), we cannot rule out that real-world proxies include

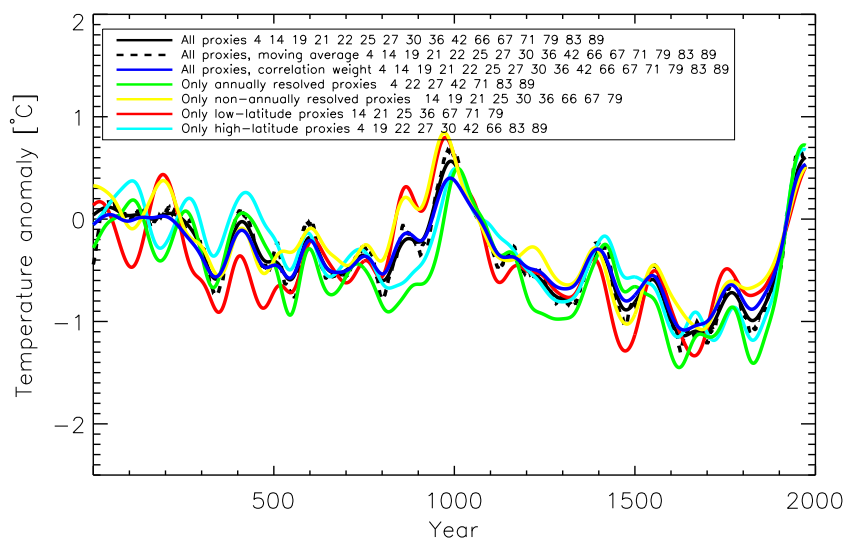

Fig. 12. Reconstruction of the extra-tropical NH mean temperature $\left({ }^{\circ} \mathrm{C}\right)$ based on the gray-shaded proxies in Table 1 reaching back to $300 \mathrm{AD}$. The full black curve shows the reconstruction of Fig. 5. The dashed black curve shows this reconstruction but now smoothed with a moving average filter as used in Christiansen and Ljungqvist (2011). The blue curve shows a reconstruction where local reconstructions are weighted according to the correlation between the proxy and the local temperature. The green curve shows a reconstruction based only on proxies of annual resolution, while the yellow curve shows a reconstruction based only in proxies of annual-to-decadal and decadal resolution. The red and light blue curves show reconstructions based on proxies north and south of $60^{\circ} \mathrm{N}$, respectively. Only proxies with positive correlations and a $p$-value less than 0.01 are used. The included proxies are given in the legend. The calibration period is 1880-1960 AD. All reconstructions are 50-yr smoothed and centered to zero mean in 1880-1960 AD.

low-frequency noise components that are not represented in the pseudo-proxies and which can disturb the effect of temporal averaging. It is therefore interesting to study how stable the LOC based real-world reconstructions are to the degree of spatial averaging, i.e. to the number of included proxies. The large number of proxies in the present study gives us a chance to do this.

Figures 8 and 9 show reconstructions of the LIA based on different numbers of proxies (from 16 to 55 after screening). We note that they all agree on a minimum anomaly around $1600 \mathrm{AD}$ close to $-1.0^{\circ} \mathrm{C}$ lower than the temperature in the calibration period 1880-1960 AD (50-yr smoothed). Christiansen and Ljungqvist (2011) presented a LOC reconstruction of the extra-tropical $\mathrm{NH}$ mean temperature in last millennium based on 23 proxies (selected by screening 40 proxies). In this study the cold anomaly was found to be $-1.1^{\circ} \mathrm{C}$. The different reconstructions disagree more about the temperature minima in the 19th century, but the $50-\mathrm{yr}$ smoothed reconstructions generally fall inside the $95 \%$ confidence interval calculated by the ensemble pseudo-proxy method. Furthermore, there does not seem to be a systematic reduction in the reconstructed temperature with an increasing number of proxies; in fact, the coldest reconstruction is 
the one based on the largest number of proxies (red curve in Fig. 9, calibration period 1880 AD-last year). These results suggest that the effect of low-frequency noise is small and that LOC reconstructs 50-yr smoothed values well.

\subsection{Validation}

As mentioned, the LOC reconstruction method only reconstructs low-frequency variability confidently, while high-frequency variability is overestimated. This makes validation exercises difficult with only $80-100 \mathrm{yr}$ of observations, as discussed in Christiansen (2011) and Christiansen and Ljungqvist (2011). This is one reason why we use the surrogate ensemble method to investigate the quality of the method and to provide confidence intervals on the reconstructions. In Figs. 5 and 8 we have plotted the observed extra-tropical $\left(>30^{\circ} \mathrm{N}\right)$ annual mean temperature (green curves), and also the annual mean temperature averaged over grid-cells with accepted proxies (yellow curves) for the period 1880-2000 AD. Despite the possible effects of smoothing, it is clear that the LOC reconstructions overestimate the variability somewhat. This is perhaps most clearly seen in the periods 1880-1900 AD where the reconstructions are too cold and in the period 1930-1950 AD where it is too warm. Only a smaller part this overestimation can be attributed to the limited number of grid-cells.

While such an overestimation is not seen systematically in the ensemble pseudo-proxy studies, this does not rule out the possibility for the observed overestimation to be a chance occurrence. Another, perhaps more realistic, possibility is that the proxies not only represent local temperatures but also the extra-tropical NH mean itself. This would violate an important assumption of the LOC method and lead to an overestimation of the low-frequency variability in the calibration period. The influence in the reconstruction period could be both an overestimation or an underestimation, depending on the reason why the proxies respond to the extra-tropical $\mathrm{NH}$ mean temperature. One such reason might be that the proxies are sensitive to precipitation which, through teleconnections, could show up as a sensitivity to the extra-tropical NH mean. Another reason could be that proxies showing a strong 20th century warming have been favored in some step in the proxy selection process. Further work is needed to investigate how such complications influence the behaviour of both LOC and other reconstruction methods.

Christiansen and Ljungqvist (2011) (Sect. 8) performed a leave-one-out cross-validation test of the correlation between the reconstruction and $\mathrm{NH}$ temperature based on annually resolved proxies. We find almost similar results when repeating the test on the reconstructions in the present paper. Under the same conditions as for the 500-yr long reconstruction in Fig. 8, we obtain a correlation coefficient of 0.84 between the reconstruction and the observations in the calibration period. As in Christiansen and Ljungqvist (2011), this high correlation is partly a result of the trends in the calibration period; after detrending the correlation is 0.44 . The corresponding numbers under the conditions of the two-millennia long reconstruction in Fig. 5 are 0.81 before detrending and 0.53 after detrending.

\section{Conclusions}

We have compiled a set of 91 temperature sensitive proxies located in the extra-tropical $\mathrm{NH}$ that reach back to at least $1500 \mathrm{AD}$. All the proxies have been published in the peer reviewed literature. Of these proxies, 32 extend as far back as to the beginning of the first millennium. From these comprehensive proxy compilations we performed new reconstructions of the extra-tropical NH mean temperature. Note, however, that only little more than half of the proxies (the exact fraction depends on the calibration interval, etc.) correlate well enough with the local annual mean temperature to be included in the actual reconstructions.

The reconstructions are carried out with the LOC method (Christiansen, 2011), which was designed to preserve lowfrequency variability at the price of exaggerating the highfrequency variability. The LOC method accomplishes this by obtaining local temperature reconstructions using linear regression, with temperature as the independent variable. This corresponds to a forward model which is the physical sound choice. The local reconstructions are then combined to a reconstruction of the extra-tropical $\mathrm{NH}$ mean temperature by simple averaging, thereby avoiding the complications of more complex spatial covariance models. Confidence intervals have been calculated with an ensemble pseudo-proxy approach which mimics the conditions of our real-world reconstructions, including the spatial and temporal averaging. These calculations indicate that the extra-tropical $\mathrm{NH}$ mean reconstructions have only a small bias. The corresponding $95 \%$ confidence intervals have widths of 0.6 (twomillennia long reconstruction) and $0.4{ }^{\circ} \mathrm{C}(500$-yr long reconstruction) for 50 -yr smoothed values, thereby showing that the residual noise-variance is relatively small compared to the reconstructed low-frequency signal.

Our main conclusions are as follows.

- Our reconstructions indicate - in agreement with the results of Moberg et al. (2005); Ljungqvist (2010), and Loehle and McCulloch (2008) - that the first millennium $\mathrm{AD}$ was generally significantly warmer than the second millennium AD. The 17th century was the coldest century during the last two millennia and most of the LIA seems to have been colder than during the Dark Age Cold Period ca. 300-800 AD. In general, our LOC reconstructions show larger low-frequency variability than previous reconstructions.

- Our two-millennia long reconstruction has a welldefined peak in the period $950-1050 \mathrm{AD}$ with a maximum temperature anomaly of $0.6^{\circ} \mathrm{C}$. The timing of 
the peak of the MWP in our reconstruction is in agreement with the reconstructions of Esper et al. (2002a) and Ljungqvist (2010). The reconstructions of Mann et al. $(2008,2009)$ show a longer peak warming covering the whole period $950-1100 \mathrm{AD}$, and the reconstruction of Moberg et al. (2005) shows a somewhat later as well as longer peak MWP warming than in the present paper. The level of warmth during the peak of the MWP in the second half of the 10th century, equalling or slightly exceeding the mid-20th century warming, is in agreement with the results from other more recent large-scale multi-proxy temperature reconstructions by Moberg et al. (2005), Mann et al. (2008, 2009), Ljungqvist (2010), and Ljungqvist et al. (2012).

- Temperatures in the 17 th century reach values as cold as $-1.0^{\circ} \mathrm{C}$ below the $1880-1960 \mathrm{AD}$ level, in agreement with a previous LOC reconstruction by Christiansen and Ljungqvist (2011) based on fewer proxies. We find that this result is very robust relative to the calibration period and the number of proxies included. This level of cooling is considerably colder than obtained with other reconstruction methods (see also Christiansen and Ljungqvist (2011) for additional comparison). In the 19th century temperature anomalies reach values of ca. $-0.9{ }^{\circ} \mathrm{C}$, but this value is somewhat more sensitive to the calibration period. The two temperature minima are separated by a local maximum in the 18th century. This temporal variation of the temperature throughout the LIA is in line with most previous work. Most regional to global multi-proxy temperature reconstructions studies agree that the 17 th century was the coldest century during the LIA (Ljungqvist, 2010; Ljungqvist et al., 2012; Hegerl et al., 2007; Mann et al., 2008, 2009; Moberg et al., 2005; National Research Council, 2006), although high-latitude summer temperatures seem to have reached a minimum in the 19th century (Grudd, 2008; Kaufman et al., 2009; Ran et al., 2011; Vinther et al., 2010; Sicre et al., 2011). The maximum cooling in the 17th century is also supported by General Circulation Models and Energy Balance Models (Ammann et al., 2007; Friend, 2011; GonzálezRouco et al., 2006; Jungclaus et al., 2010; Servonnat et al., 2010; Hofer et al., 2011; Swingedouw et al., 2011) using state-of-the-art estimates of past radiative forcing. The 18th century is generally found to be warmer than both the 17th and the 19th centuries with, regionally, temperatures as high as in the mid-20th century.

- We find that the LIA is spatially homogeneous with cold anomalies everywhere and almost the same patterns in the 17th and the 19th centuries. The homogeneity of the LIA is in agreement with previous work (Juckes et al., 2007; Matthews and Briffa, 2005; National Research Council, 2006; Wanner et al., 2008, 2011; Ljungqvist et al., 2012). The MWP seems more inhomogeneous, as has also been suggested in several previous studies, including Bradley et al. (2003), Hughes and Diaz (1994), Diaz et al. (2011) and Mann et al. (2009). However, we find that the statistical significance is low due to the limited number of proxies, in agreement with Esper and Frank (2009) who suggested that the use of relatively few noisy and poorly replicated proxies can give a false impression of heterogeneity. Ljungqvist et al. (2012) show that, on centennial timescales, the MWP is no less homogeneous than the LIA if all available proxy evidence, including low-resolution records, are taken into consideration in order to give a better spatial data coverage.

- The large number of proxies allow us to compare LOC reconstruction based on different number of proxies and thereby test the influence of the spatial averaging. Reconstructions based on 16 to 55 proxies (after screening) show only small differences in 50-yr smoothed temperatures that generally fall inside the $95 \%$ confidence interval calculated by the ensemble pseudo-proxy method. This suggests that low-frequency noise is a minor problem and that LOC reconstructs 50-yr smoothed extratropical $\mathrm{NH}$ mean temperatures well.

Acknowledgements. This work was supported by the Danish Climate Centre at the Danish Meteorological Institute. The HadCRUT3v was downloaded from http://www.cru.uea.ac.uk/cru/data/temperature/. We want to thank the contributers to the World Data Center for Paleoclimatology as well as all the scholars that willingly shared their published but un-archived proxy data with us.

Edited by: N. Abram

\section{References}

Ammann, C. M., Joos, F., Schimel, D. S., Otto-Bliesner, B. L., and Thomas, R. A.: Solar influence on climate during the past millennium: results from transient simulations with the NCAR Climate System Model, Proc. Natl. Acad. Sci. USA, 104, 3713-3718, 2007.

Andersson, C., Pausata, F. S. R., Jansen, E., Risebrobakken, B., and Telford, R. J.: Holocene trends in the foraminifer record from the Norwegian Sea and the North Atlantic Ocean, Clim. Past, 6, 179-193, doi:10.5194/cp-6-179-2010, 2010.

Biondi, F., Perkins, D. L., Cayan, D. R., and Hughes, M. K.: July temperature during the second millennium reconstructed from Idaho tree rings, Geophys. Res. Lett., 26, 1445-1448, 1999.

Bird, B., Abbott, M., Finney, B., and Kutchko, B.: A 2000 year varve-based climate record from the Central Brooks Range, Alaska, J. Paleolimnol., 41, 25-41, 2009.

Bolshyanov, D. Y. Makeev, V. M.: Severnaya Zemlia ArchipelagoGlaciation, Development of the Environments (Arkhipelag Severnaya Zemlia - Oldenneniye, Istoriya Razvitiya Prirodnoy Sredy), Gidrometeoizdat, Sankt-Petersburg, 1995 (in Russian). 
Bradley, R. S.: Paleoclimatology: Reconstructing climates of the Quaternary, Hardcourt/Academic Press, San Diego, CA, 2nd Edn., 1999.

Bradley, R. S., Hughes, M. K., and Diaz, H. F.: Climate in medieval time, Science, 302, 404-405, 2003.

Briffa, K. R.: Annual climate variability in the Holocene: interpreting the message of ancient trees, Quaternary Sci. Rev., 19, 87-105, 2000.

Briffa, K. R., Osborn, T. J., Schweingruber, F. H., Harris, I. C., Jones, P. D., Shiyatov, S. G., and Vaganov, E. A.: Low-frequency temperature variations from a northern tree ring density network, J. Geophys. Res., 106, 2929-2941, 2001.

Briffa, K. R., Shishov, V. V., Melvin, T. M., Vaganov, E. A., Grudd, H., Hantemirov, R. M., Eronen, M., and Naurzbaev, M. M.: Trends in recent temperature and radial tree growth spanning 2000 years across Northwest Eurasia, Philos. T. Roy. Soc. B, 363, 2271-2284, 2008.

Broecker, W. S.: Was the medieval warm period global?, Science, 291, 1497-1499, 2001.

Brohan, P., Kennedy, J., Haris, T., Tett, S. F. B., and Jones, P. D.: Uncertainty estimates in regional and global observed temperature changes: a new dataset from 1850, J. Geophys. Res., 111, D12106, doi:10.1029/2005jd006548, 2006.

Büntgen, U., Frank, D. C., Nievergelt, D., and Esper, J.: Summer temperature variations in the European Alps, AD 755-2004, J. Climate, 19, 5606-5623, 2006.

Büntgen, U., Frank, D. C., Grudd, H., and Esper, J.: Long-term summer temperature variations in the Pyrenees, Clim. Dynam., 31, 615-631, 2008.

Büntgen, U., Tegel, W., Nicolussi, K., McCormick, M., Frank, D., Trouet, V., Kaplan, J. O., Herzig, F., Heussner, K.-U., and Wanner, H.: 2500 years of European climate variability and human susceptibility, Science, 331, 578-582, 2011.

Bürger, G. and Cubasch, U.: Climate reconstruction by regression - 32 variations on a theme, Tellus A, 58, 227-235, 2006.

Christiansen, B.: Reconstructing the NH mean temperature: can underestimation of trends and variability be avoided?, J. Climate, 24, 674-692, 2011.

Christiansen, B.: Reply to "Comments on Reconstructing the NH mean temperature: Can underestimation of trends and variability be avoided?" by Tingley and Li, J., Climate, accepted, doi:10.1175/JCLI-D-11-00162.1, 2012.

Christiansen, B. and Ljungqvist, F. C.: Reconstruction of the extratropical $\mathrm{NH}$ mean temperature over the last millennium with a method that preserves low-frequency variability, J. Climate, 24, 6013-6034, 2011.

Christiansen, B. and Ljungqvist, F. C.: Reply to Comments on "Reconstruction of the extra-tropical NH mean temperature over the last millennium with a method that preserves low-frequency variability" by A. Moberg, J. Climate, submitted, available online at: http://web.dmi.dk/fsweb/solar-terrestrial/staff/boc/reply_ to_moberg.pdf, 2012.

Christiansen, B., Schmith, T., and Thejll, P.: A surrogate ensemble study of climate reconstruction methods: stochasticity and robustness, J. Climate, 22, 951-976, 2009.

Christiansen, B., Schmith, T., and Thejll, P.: Reply to Comment on "A surrogate ensemble study of climate reconstruction methods: stochasticity and robustness" by Rutherford, S., Mann, M. E., Ammann, C., and Wahl, E., J. Climate, 23, 2839-2844, 2010.
Chuine, I., Yiou, P., Viovy, N., Seguin, B., Daux, V., and Ladurie, E. L. R.: Grape ripening as a past climate indicator, Nature, 432, 289-290, 2004.

Cook, T. L., Bradley, R. S., Stoner, J. S., and Francus, P.: Five thousand years of sediment transfer in a High Arctic watershed recorded in annually laminated sediments from Lower Murray Lake, Ellesmere Island, Nunavut, Canada, J. Paleolimnol., 41, 77-94, 2009.

Corona, C., Edouard, J.-L., Guibal, F., Guiot, J., Bernard, S., Thomas, A., and Denelle, N.: Long-term summer (AD 7512008) temperature fluctuation in the French Alps based on treering data, Boreas, 40, 351-366, 2011.

Cronin, T. M., Dwyer, G. S., Kamiya, T., Schwede, S., and Willard, D. A.: Medieval Warm Period, Little Ice Age and 20th century temperature variability from Chesapeake Bay, Global Planet. Change, 36, 17-29, 2003.

Cronin, T. M., Hayo, K., Thunell, R. C., Dwyer, G. S., Saenger, C. P., and Willard, D. A.: The Medieval Climate Anomaly and Little Ice Age in Chesapeake Bay and the North Atlantic Ocean, Palaeogeogr. Palaeocl., 297, 299-310, 2010.

Dansgaard, W., Johnsen, S. J., Möller, J., and C. C. Langway, J.: One thousand centuries of climatic record from Camp Century on the Greenland ice sheet, Science, 166, 377-381, 1969.

D’Arrigo, R., Jacoby, G., Frank, D., Pederson, N., Cook, E., Buckley, B., Nachin, B., Mijiddorj, R., and Dugarjav, C.: 1738 years of Mongolian temperature variability inferred from a tree-ring width chronology of Siberian pine, Geophys. Res. Lett., 28, 543546, 2001.

D’Arrigo, R., Mashig, E., Frank, D., Wilson, R., and Jacoby, G.: Temperature variability over the past millennium inferred from Northwestern Alaska tree rings, Clim. Dynam., 24, 227-236, 2005.

D’Arrigo, R., Wilson, R., and Jacoby, G.: On the long-term context for late twentieth century warming, J. Geophys. Res., 111, D03103, doi:10.1029/2005JD006352, 2006.

Diaz, H. F., Trigo, R., Hughes, M. K., Mann, M. E., Xoplaki, E., and Barriopedro, D.: Spatial and temporal characteristics of climate in Medieval times revisited, B. Am. Meteorol. Soc., 92, 14871500, 2011.

Dobrovolný, P., Moberg, A., Brázdil, R., Pfister, C., Glaser, R., Wilson, R., van Engelen, A., Limanówka, D., Kiss, A., Halíčková, M., Macková, J., Riemann, D., Luterbacher, J., and Böhm, R.: Monthly, seasonal and annual temperature reconstructions for Central Europe derived from documentary evidence and instrumental records since AD 1500, Climatic Change, 101, 69107, 2010.

Edwards, T. W. D., Birks, S. J., Luckman, B. H., and MacDonald, G. M.: Climatic and hydrologic variability during the past millennium in the Eastern Rocky Mountains and Northern Great Plains of Western Canada, Quaternary Res., 70, 188-197, 2008.

Eichler, A., Olivier, S., Henderson, K., Laube, A., Beer, J., Papina, T., Gäggeler, H. W., and Schwikowski, M.: Temperature response in the Altai region lags solar forcing, Geophys. Res. Lett., 36, L01808, doi:10.1029/2008GL035930, 2009.

Esper, J. and Frank, D. C.: IPCC on heterogeneous medieval warm period, Climatic Change, 94, 267-273, 2009.

Esper, J., Cook, E. R., and Schweingruber, F. H.: Low-frequency signals in long tree-ring chronologies for reconstructing past temperature variability, Science, 295, 2250-2253, 2002a. 
Esper, J., Schweingruber, F. H., and Winiger, M.: 1300 years of climatic history for Western Central Asia inferred from tree-rings, Holocene, 12, 267-277, 2002b.

Esper, J., Shiyatov, S. G., Mazepa, V. S., Wilson, R. J. S., Graybill, D. A., and Funkhouser, G.: Temperature-sensitive Tien Shan tree ring chronologies show multi-centennial growth trends, Clim. Dynam., 8, 699-706, 2003.

Fisher, D. A., Koerner, R. M., Paterson, W. S. B., Dansgaard, W., Gundestrup, N., and Reeh, N.: Effect of wind scouring on climatic records from icecore oxygen isotope profiles, Nature, 301, 205-209, 1983.

Frank, D., Esper, J., Zorita, E., and Wilson, R.: A noodle, hockey stick, and spaghetti plate: a perspective on highresolution paleoclimatology, WIREs Climatic Change, 1, 507516, doi:10.1002/wcc.53, 2010.

Friend, A. D.: Response of Earth's surface temperature to radiative forcing over A.D. 1-2009, J. Geophys. Res., 116, D13112, doi:10.1029/2010JD015143, 2011.

Frisia, S., Borsato, A., Preto, N., and McDermott, F.: Late Holocene annual growth in three Alpine stalagmites records the influence of solar activity and the North Atlantic Oscillation on winter climate, Earth Planet. Sci. Lett., 216, 411-424, 2003.

Gajewski, K.: Late Holocene climate changes in Eastern North America estimated from pollen data, Quaternary Res., 29, 255 $262,1988$.

Ge, Q., Zheng, J., Fang, X., Man, Z., Zhang, X., Zhang, P., and Wang, W.-C.: Winter half-year temperature reconstruction for the middle and lower reaches of the Yellow River and Yangtze River, China, during the past 2000 years, Holocene, 13, 933-940, 2003.

Geirsdóttir, A., Miller, G. H., Thordarson, T., and Ólafsdóttir, K. B.: A 2000 year record of climate variations reconstructed from Haukadalsvatn, West Iceland, J. Paleolimnol., 41, 95-115, 2009.

Glaser, R. and Riemann, D.: A thousand-year record of temperature variations for Germany and Central Europe based on documentary data, J. Quaternary Sci., 24, 437-449, 2009.

González-Rouco, J. F., Beltrami, H., Zorita, E., and von Storch, H.: Simulation and inversion of borehole temperature profiles in surrogate climates: spatial distribution and surface coupling, Geophys. Res. Lett., 33, L01703, doi:10.1029/2005GL024693, 2006.

Graumlich, L. J.: A 1000-year record of temperature and precipitation in the Sierra Nevada, Quaternary Res., 39, 249-255, 1993.

Gray, B. M.: Early Japanese winter temperatures, Weather, 29, 103 107, 1974.

Grootes, P. M. and Stuiver, M.: Oxygen 18/16 variability in Greenland snow and ice with $10^{3}$ to $10^{5}$-year time resolution, J. Geophys. Res., 102, 26455-26470, 1997.

Groveman, B. S. and Landsberg, H. E.: Simulated Northern Hemisphere temperature departures 1579-1880, Geophys. Res. Lett., 6, 767-770, 1979.

Grudd, H.: Torneträsk tree-ring width and density AD 500-2004: a test of climatic sensitivity and a new 1500-year reconstruction of North Fennoscandian summers, Clim. Dynam., 31, 843-857, 2008.

Grudd, H., Briffa, K. R., Karlén, W., Bartholin, T. S., Jones, P. D., and Kromer, B.: A 7400-year tree-ring chronology in Northern Swedish Lapland: natural climatic variability expressed on annual to millennial timescales, Holocene, 12, 657-665, 2002.

Hegerl, G. C., Crowley, T. J., Allen, M., Hyde W. T., and Pollack, H.
N.: Detection of human influence on a new, validated 1500 -year temperature reconstruction, J. Climate, 20, 650-666, 2007.

Helama, S., Fauria, M., Mielikäinen, K., Timonen, M., and Eronen, M.: Sub-Milankovitch solar forcing of past climates: mid and late Holocene perspectives, Bull. Geol. Soc. Am., 122, 1981-1988, 2010

Hofer, D., Raible, C. C., and Stocker, T. F.: Variations of the Atlantic meridional overturning circulation in control and transient simulations of the last millennium, Clim. Past, 7, 133-150, doi:10.5194/cp-7-133-2011, 2011.

Hu, C., Henderson, G. M., Huang, J., Xie, S., Sun, Y., and Johnson, K. R.: Quantification of Holocene Asian monsoon rainfall from spatially separated cave records, Earth. Planet. Sci. Lett., 266, 221-232, 2008.

Huang, S. P., Pollack, H. N., and Shen, P.-Y.: A late Quaternary climate reconstruction based on borehole heat flux data, borehole temperature data, and the instrumental record, Geophys. Res. Lett., 35, L13703, doi:10.1029/2008GL034187, 2008.

Hughes, M. K. and Diaz, H. F.: Was there a "medieval warm period", and if so, where and when?, Climatic Change, 26, 109142,1994

Hughes, M. K., Vaganov, E. A., Shiyatov, S., Touchan, R., and Funkhouser, G.: Twentieth-century summer warmth in Northern Yakutia in a 600-year context, Holocene, 9, 629-634, 1999.

Isaksson, E., Divine, D., Kohler, J., Martma, T., Pohjola, V., Motoyama, H., and Watanabe, O.: Climate oscillations as recorded in Svalbard ice core $\delta^{18} \mathrm{O}$ records between $1200-1997 \mathrm{AD}, \mathrm{Ge}-$ ogr. Ann., 87A, 203-214, 2005.

Jacoby, G. J., D’Arrigo, R., and Davaajamts, T.: Mongolian tree rings and 20th-century warming, Science, 273, 771-773, 1996.

Jones, P. D. and Bradley, R. A.: Climatic variations over the last 500 years, in: Climate since AD 1500, edited by: Jones, P. D. and Bradley, R. A., Routledge, London, 649-665, 1992.

Jones, P. D., Osborn, T. J., and Briffa, K. R.: Estimating sampling errors in large-scale temperature averages, J. Climate, 10, 2548 2568, 1997.

Jones, P. D., Briffa, K. R., and Osborn, T. J.: Changes in the Northern Hemisphere annual cycle: Implications for paleoclimatology?, J. Geophys. Res., 108, 4588, doi:10.1029/2003JD003695, 2003.

Jones, P. D., Briffa, K. R., Osborn, T. J., Lough, J. M., van Ommen, T. D., Vinther, B. M., Luterbacher, J., Wahl, E. R., Zwiers, F. W., Mann, M. E., Schmidt, G. A., Ammann, C. M., Buckley, B. M., Cobb, K. M., Esper, J., Goosse, H., Graham, N., Jansen, E., Kiefer, T., Kull, C., Küttel, M., Mosley-Thompson, E., Overpeck, J. T., Riedwyl, N., Schulz, M., Tudhope, A. W., Villalba, R., Wanner, H., Wolff, E., and Xoplak, E.: High-resolution palaeoclimatology of the last millennium: A review of current status and future prospects, Holocene, 19, 3-49, 2009.

Juckes, M. N., Allen, M. R., Briffa, K. R., Esper, J., Hegerl, G. C., Moberg, A., Osborn, T. J., and Weber, S. L.: Millennial temperature reconstruction intercomparison and evaluation, Clim. Past, 3, 591-609, doi:10.5194/cp-3-591-2007, 2007.

Jungclaus, J. H., Lorenz, S. J., Timmreck, C., Reick, C. H., Brovkin, V., Six, K., Segschneider, J., Giorgetta, M. A., Crowley, T. J., Pongratz, J., Krivova, N. A., Vieira, L. E., Solanki, S. K., Klocke, D., Botzet, M., Esch, M., Gayler, V., Haak, H., Raddatz, T. J., Roeckner, E., Schnur, R., Widmann, H., Claussen, M., Stevens, B., and Marotzke, J.: Climate and carbon- 
cycle variability over the last millennium, Clim. Past, 6, 723737, doi:10.5194/cp-6-723-2010, 2010.

Kalugin, I. A., Daryin, A. V., and Babich, V. V.: Reconstruction of annual air temperatures for three thousand years in Altai region by lithological and geochemical indicators in Teletskoe Lake sediments, Dokl. Earth Sci., 426, 681-684, 2009.

Kaufman, D. S., Schneider, D. P., McKay, N. P., Ammann, C. M., Bradley, R. S., Briffa, K. R., Miller, G. H., Otto-Bliesner, B. L., Overpeck, J. T., and Vinther, B. M.: Recent warming reverses long-term Arctic cooling, Science, 325, 1236-1239, 2009.

Kirchhefer, A. J.: Reconstruction of summer temperatures from tree-rings of Scots pine (Pinus sylvestris L.) in coastal Northern Norway, Holocene, 11, 41-52, 2001.

Klimenko, V. V., Klimanov, V. A., Sirin, A. A., and Sleptsov, A. M.: Climate changes in Western European Russia in the Late Holocene, Dokl. Earth Sci., 377, 190-194, 2001.

Kobashi, T., Severinghaus, J. P., Barnola, J.-M., Kawamura, K., Carter, T., and Nakaegawa, T.: Persistent multi-decadal Greenland temperature fluctuation through the last millennium, Climatic Change, 100, 733-756, 2010.

Lamoureux, S. F. and Bradley, R. S.: A late Holocene varved sediment record of environmental change from Northern Ellesmere Island, J. Paleolimnol., 16, 239-255, 1996.

Larocque-Tobler, I., Grosjean, M., Heiri, O., Trachsel, M., and Kamenik, C.: Thousand years of climate change reconstructed from chironomid subfossils preserved in varved lake Silvaplana, Engadine, Switzerland, Quaternary Sci. Rev., 29, 1940-1949, 2010.

Leijonhufvud, L., Wilson, R., Moberg, A., Söderberg, J., Retsö D., and Söderlind, U.: Five centuries of Stockholm winter/spring temperatures reconstructed from documentary evidence and instrumental observations, Climatic Change, 101, 109-141, 2010.

Linderholm, H. W. and Gunnarson, B. E.: Summer temperature variability in central Scandinavia during the last 3600 years, Geogr. Ann. A, 87, 231-241, 2005.

Lindholm, M., Jalkanen, R., Salminen, H., Aalto, T., and Ogurtsov, M.: The height increment record of summer temperature extended over the last millennium in Fennoscandia, Holocene, 21, 319-326, 2011.

Ljungqvist, F. C.: A new reconstruction of temperature variability in the extra-tropical Northern Hemisphere during the last two millennia, Geogr. Ann. A, 92, 339-351, 2010.

Ljungqvist, F. C., Krusic, P. J., Brattström, G., and Sundqvist, H. S.: Northern Hemisphere temperature patterns in the last 12 centuries, Clim. Past, 8, 227-249, doi:10.5419/cp-8-227-2012, 2012.

Loehle, C. and McCulloch, J. H.: Correction to: A 2000-year global temperature reconstruction based on non-tree ring proxies, Energy and Environment, 19, 93-100, 2008.

Loso, M. G.: Summer temperatures during the Medieval Warm Period and Little Ice Age inferred from varved proglacial lake sediments in Southern Alaska, J. Paleolimnol., 41, 117-128, 2009.

Luckman, B. H. and Wilson, R. J. S.: Summer temperatures in the Canadian Rockies during the last millennium: a revised record, Clim. Dynam., 24, 131-144, 2005.

Luckman, B. H., Briffa, K. R., Jones, P. D., and Schweingruber, F. H.: Tree-ring based reconstruction of summer temperatures at the Columbia Icefield, Alberta, Canada, AD 1073-1983, Holocene, 7, 375-389, 1997.

Mann, M. E., Bradley, R. S., and Hughes, M. K.: Global-scale tem- perature patterns and climate forcing over the past six centuries, Nature, 392, 779-787, 1998.

Mann, M. E., Bradley, R. S., and Hughes, M. K.: Northern Hemisphere temperatures during the past millennium: inferences, uncertainties, and limitations, Geophys. Res. Lett., 26, 759-762, 1999.

Mann, M. E., Zhang, Z., Hughes, M. K., Bradley, R. S., Miller, S. K., Rutherford, S., and Ni, F.: Proxy-based reconstructions of hemispheric and global surface temperature variations over the past two millennia, Proc. Natl. Acad. Sci. USA, 105, 13252-13257, 2008.

Mann, M. E., Zhang, Z., Rutherford, S., Bradley, R. S., Hughes, M. H., Shindell, D., Ammann, C., Faluvegi, G., and $\mathrm{Ni}, \mathrm{F}$.: Global signatures and dynamical origins of the Little Ice Age and Medieval Climate Anomaly, Science, 326, 1256-1260, 2009.

Matthews, J. A. and Briffa, K. R.: The "Little Ice Age": reevaluation of an evolving concept, Geogr. Ann. A, 87, 17-36, 2005.

McKay, N. P., Kaufman, D. S., and Michelutti, N.: Biogenic silica concentration as a high-resolution, quantitative temperature proxy at Hallet Lake, South-Central Alaska, Geophys. Res. Lett., 35, L055709, doi:10.1029/2007GL032876, 2008.

Moberg, A.: Comments on "Reconstruction of the extra-tropical $\mathrm{NH}$ mean temperature over the last millennium with a method that preserves low-frequency variability", J. Climate, submitted, 2012.

Moberg, A., Sonechkin, D. M., Holmgren, K., Datsenko, N. M., and Karlén, W.: Highly variable Northern Hemisphere temperatures reconstructed from low- and high-resolution proxy data, Nature, 433, 613-617, 2005.

Moberg, A., Sonechkin, D. M., Holmgren, K., Datsenko, N. M., Karlén, W., and Lauritzen, S.-E.: Corrigendum: Highly variable Northern Hemisphere temperatures reconstructed from low- and high-resolution proxy data, Nature, 439, 1014, doi:10.1038/nature04575, 2006.

Moore, J. J., Hughen, K. A., Miller, G. H., and Overpeck, J. T.: Little Ice Age recorded in summer temperature reconstruction from varved sediments of Donard Lake, Baffin Island, Canada, J. Paleolimnol., 25, 503-517, 2001.

Mǒzný, M., Brázdil, R., Dobrovolný, O., and Trnka, M.: Cereal harvest dates in the Czech Republic between 1501 and 2008 as a proxy for March-June temperature reconstruction, Climatic Change, 110, 801-821, 2012.

National Research Council: Surface temperature reconstructions for the Last 2000 years, National Academies Press, Washington, DC, 2006.

Naurzbaev, M. M., Vaganov, E. A., Sidorova, O. V., and Schweingruber, F. H.: Summer temperatures in Eastern Taimyr inferred from a 2427-year late-Holocene tree-ring chronology and earlier floating series, Holocene, 12, 727-736, 2002.

NGRIP members: High-resolution record of Northern Hemisphere climate extending into the last interglacial period, Nature, 431, 147-151, 2004.

Popa, I. and Kern, Z.: Long-term summer temperature reconstruction inferred from tree-ring records from the Eastern Carpathians, Clim. Dynam., 32, 1107-1117, 2009.

Proctor, C. J., Baker, A., and Barnes, W. L.: A three thousand year record of North Atlantic climate, Clim. Dynam., 19, 449-454, 
2002.

Qiang, M.-R., Chen, F.-H., Zhang, J.-W., Gao, S.-Y., and Zhou, A.F.: Climatic changes documented by stable isotopes of sedimentary carbonate in Lake Sugan, Northeastern Tibetan Plateau of China, since 2 ka BP, Chinese Sci. Bull., 50, 1930-1939, 2005.

Ran, L., Jiang, H., Knudsen, K. L., and Eiríksson, J.: Diatom-based reconstruction of palaeoceanographic changes on the North Icelandic shelf during the last millennium, Palaeogeogr. Palaeocl., 302, 109-119, 2011.

Salzer, M. W. and Kipfmueller, K. F.: Reconstructed temperature and precipitation on a millennial timescale from tree-rings in the Southern Colorado Plateau, USA, Climatic Change, 70, 465487, 2005

Servonnat, J., Yiou, P., Khodri, M., Swingedouw, D., and Denvil, S.: Influence of solar variability, $\mathrm{CO}_{2}$ and orbital forcing between 1000 and AD 1850 in the IPSLCM4 model, Clim. Past, 6, 445460, doi:10.5194/cp-6-445-2010, 2010.

Sicre, M.-A., Hall, I. R., Mignot, J., Khodri, M., Ezat, U., Truong, M.-X., Eiríksson, J., and Knudsen, K.-L.: Sea surface temperature variability in the subpolar Atlantic over the last two millennia, Paleoceanography, 26, PA4218, doi:10.1029/2011PA002169, 2011.

Sidorova, O. V., Vaganov, E. A., Naurzbaev, M. M., Shishov, V. V., and Hughes, M. K.: Regional features of the radial growth of larch in North Central Siberia according to millennial tree-ring chronologies, Russ. J. Ecol., 38, 90-93, 2007.

Sleptsov, A. M. and Klimenko V. V.: Multi-proxy reconstruction of the climate of Eastern Europe during the last 2000 years, Izvestiya of the Russian Geographical Society, 6, 45-54, 2003 (in Russian).

Smerdon, J. E. and Kaplan, A.: Comments on "Testing the fidelity of methods used in proxy-based reconstructions of past climate": The role of the standardization interval, J. Climate, 20, 5666$5670,2007$.

Smerdon, J. E., Kaplan, A., Zorita, A., González-Rouco, J. F., and Evans, M. N.: Spatial performance of four climate field reconstruction methods targetting the Common Era, Geophys. Res. Lett., 38, L11795, doi:10.1029/2011GL047372, 2011.

Solomon, S., Qin, D., Manning, M., Chen, Z., Marquis, M., Averyt, K. B., Tignor, M., and Miller, H. L.: Contribution of Working Group I to the Fourth Assessment Report of the Intergovernmental Panel on Climate Change, 2007.

Stendel, M., Mogensen, I. A., and Christensen, J. H.: Influence of various forcings on global climate in historical times using a coupled atmosphere-ocean general circulation model, Clim. Dynam., 26, 1-15, 2006.

Sundqvist, H. S., Holmgren, K., Moberg, A., Spötl, C., and Mangini, A.: Stable isotopes in a stalagmite from NW Sweden document environmental changes over the past 4000 years, Boreas, 39, 77-86, 2010.

Swingedouw, D., Terray, L., Cassou, C., Voldoire, A., Salas-Mélia, D., and Servonnat, J.: Natural forcing of climate during the last millennium: fingerprint of solar variability. Low frequency solar forcing and NAO, Clim. Dynam., 36, 1349-1364, 2011.

Tan, M., Liu, T. S., Hou, J., Qin, X., Zhang, H., and Li, T.: Cyclic rapid warming on centennial-scale revealed by a 2650 -year stalagmite record of warm season temperature, Geophys. Res. Lett., 30, 1617, doi:10.1029/2003GL017352, 2003.

Taricco, C., Ghil, M., Alessio, S., and Vivaldo, G.: Two millennia of climate variability in the Central Mediterranean, Clim. Past, 5 , 171-181, doi:10.5194/cp-5-171-2009, 2009.

Tarussov, A.: The Arctic from Svalbard to Severnaya Zemlya: climatic reconstruction from ice cores, in: Climate since AD 1500 , edited by: Bradley, R. S. and Jones, P. D., Routledge, London, 505-516, 1992.

Thomas, E. K. and Briner, J. P.: Climate of the past millennium inferred from varved proglacial lake sediments on Northeast Baffin Island, Arctic Canada, J. Paleolimnol., 41, 209-224, 2009.

Thompson, L. G., Mosley-Thompson, E., Brecher, H., Davis, M. E., Leon, B., Les, D., Mashiotta, T. A., Lin, P.-N., and Mountain, K.: Evidence of abrupt tropical climate change: past and present, Proc. Natl. Acad. Sci. USA, 103, 10536-10543, 2006.

Tingley, M. P. and Li, B.: Comments on "Reconstructing the NH mean temperature: can underestimation of trends and variability be avoided?", J. Climate, accepted, doi:10.1175/JCLI-D-1100005.1, 2012.

Tingley, M. P., Craigmile, P. F., Haran, M., Li, B., MannshardtShamseldin, E., and Rajaratnam, B.: Piecing together the past: statistical insights into paleoclimatic reconstructions, Quaternary Sci. Rev., 35, 1-25, 2012.

Treydte, K. S., Frank, D. C., Saurer, M., Helle, G., Schleser, G. H., and Esper, J.: Impact of climate and $\mathrm{CO}_{2}$ on a millennium-long tree-ring carbon isotope record, Geochim. Cosmochim. Ac., 73, 4635-4647, 2009.

van Engelen, A. F. V., Buisman, J., and IJnsen, F.: A millennium of weather, winds and water in the low countries, in: History and Climate: Memories of the Future?, edited by: Jones, P. D., Ogilvie, A. E. J., Davies, T. D., and Briffa, K. R., Kluwer Academic/Plenum Publishers, New York, 101-124, 2001.

Vinther, B. M., Johnsen, S. J., Andersen, K. K., Clausen, H. B., and Hansen, A. W.: NAO signal recorded in the stable isotopes of Greenland ice cores, Geophys. Res. Lett., 30, 1387 , doi:10.1029/2002GL016193, 2003.

Vinther, B. M., Clausen, H. B., Fisher, D. A., Koerner, R. M., Johnsen, S. J., Andersen, K. K., Dahl-Jensen, D., Rasmussen, S. O., Steffensen, J. P., and Svensson, A. M.: Synchronizing ice cores from the Renland and Agassiz ice caps to the Greenland Ice Core Chronology, J. Geophys. Res., 113, D08115, doi:10.1029/2007JD009143, 2008.

Vinther, B. M., Jones, P. D., Briffa, K. R., Clausen, H. B., Andersen, K. K., Dahl-Jensen, D., and Johnsen, S. J.: Climatic signals in multiple highly resolved stable isotope records from Greenland, Quaternary Sci. Rev., 29, 522-538, 2010.

von Storch, H., Zorita, E., Jones, J. M., Dimitriev, Y., GonzálezRouco, F., and Tett, S. F. B.: Reconstructing past climate from noisy data, Science, 306, 679-882, 2004.

Wang, S.-W., Gong, D., and Zhu, J.: Twentieth-century climatic warming in China in the context of the Holocene, Holocene, 11, 313-321, 2001.

Wanner, H., Beer, J., Bütikofer, J., Crowley, T., Cubasch, U., Flückiger, J., Goosse, H., Grosjean, M., Joos, F., Kaplan, J. O., Küttel, M., Müller, S., Pentice, C., Solomina, O., Stocker, T., Tarasov, P., Wagner, M., and Widmann, M.: Mid to late Holocene climate change - an overview, Quaternary Sci. Rev., 27, 17911828, 2008.

Wanner, H., Solomina, O., Grosjean, M., Ritz, S. P., and Jetel, M.: Structure and origin of Holocene cold events, Quaternary Sci. Rev., 30, 3109-3123, 2011. 
Yang, B., Braeuning, A., Johnson, K. R., and Yafeng, S.: General characteristics of temperature variation in China during the last two millennia, Geophys. Res. Lett., 29, 1324, doi:10.1029/2001GL014485, 2002.

Yi, L., Yu, H., Ge, J., Lai, Z., Xu, X., Qin, L., and Peng, S.: Reconstructions of annual summer precipitation and temperature in North-Central China since 1470 AD based on drought/flood index and tree-ring records, Climatic Change, 110, 469-498, 2012.

Zhang, Q., Gemmer, M., and Chen, J.: Climate changes and flood/drought risk in the Yangtze Delta, China, during the past millennium, Quaternary Int., 176-177, 62-69, 2008.
Zhang, Q.-B., Cheng, G., Yao, T., Kang, X., and Huang, J.: A 2326year tree-ring record of climate variability on the Northeastern Qinghai-Tibetan Plateau, Geophys. Res. Lett., 30, 1739, doi:10.10292003GL017425, 2003.

Zhu, H. F., Shao, X.-M., Yin, Z.-Y., Xu, P., Xu, Y., and Tian, H.: August temperature variability in the Southeastern Tibetan Plateau since AD 1385 inferred from tree rings, Palaeogeogr. Palaeocl., 305, 84-92, 2011.

Zorita, E., González-Rouco, F., and von Storch, H.: Comments on "Testing the fidelity of methods used in proxy-base reconstructions of past climate", J. Climate, 20, 3693-3698, 2007. 